Preprints of the

Max Planck Institute for

Research on Collective Goods

Bonn 2011/19

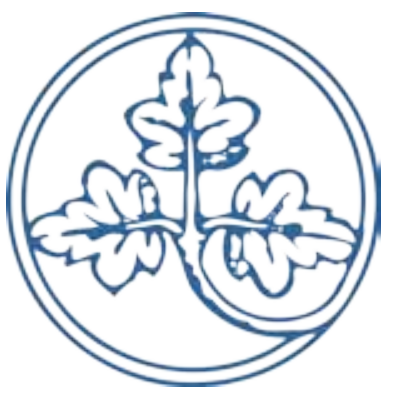

Liquidity measures, liquidity drivers and expected returns on an early call auction market

Carsten Burhop

Sergey Gelman

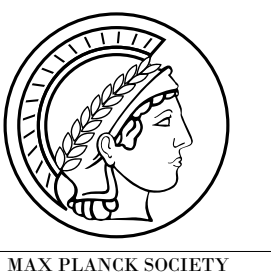




\title{
Liquidity measures, liquidity drivers and expected returns on an early call auction market
}

\author{
Carsten Burhop / Sergey Gelman
}

July 2011

This Version March 2015 


\title{
Liquidity measures, liquidity drivers, and expected returns on an early call auction market
}

\begin{abstract}
:
We analyze the impact of illiquidity on asset pricing on a rather stable stock market in a volatile economic environment, the Berlin Stock Exchange from 1892 to 1913 . We use a Lesmond et al. (1999) measure of transaction costs to proxy illiquidity. Our results show that transaction costs were low and comparable to today's costs. However, the illiquidity risk premium was considerably higher. Applying a conditional liquidity-adjusted capital asset pricing model, we show that recessions and, in particular, banking crises cause the higher illiquidity risk premia.
\end{abstract}

JEL-Classification:

G 12, G 14, N 23

Keywords:

Transaction Costs; Liquidity Premium; Liquidity Provision 


\section{Introduction}

In this paper, we empirically investigate whether liquidity is an important factor of pricing assets on a liquid and rather tranquil stock market under the presence of frequent economic shocks. By highlighting the role of consumption smoothing and wealth rebalancing we contribute to the discussion on the drivers of the liquidity risk premium. It has been shown that liquidity risk is priced, and recent findings provide for higher premiums on emerging markets than on developed markets (Lee 2011). Moreover, for the US stock market the liquidity risk premium has been shown to rise in crises times, namely during the Great Depression and oil crises in 1970s (Hagströmer et al. 2013). Emerging markets as well as US markets in crises times are characterized by lower stock market liquidity, higher volatility of returns, and a more fragile economy (stronger and more frequent shocks), which makes it difficult to empirically disentangle the driver of the liquidity risk premium.

In the literature all three features have been linked to the magnitude of the liquidity premium. First, a low liquidity itself can contribute to the premium: Beber et al (2012) derive that investors can counteract transaction costs by trading less frequently; however, if the costs are that high that they cannot be compensated by expanding the investment horizon to reasonable bounds, a higher liquidity premium results. Second, Hagströmer et al. (2013) single out stock market turbulences as the primary cause of liquidity premium increase. Hameed et al (2010) provide some indirect support for this argument, showing liquidity dry-ups after stock market declines. Third, numerous theoretical papers outline the impact of consumption shocks. Heaton and Lucas (1996) point out that labour income shocks and consumption smoothing objectives lead to a liquidity premium, which is, however, comparatively small. Acharya and Pedersen (2005) outline the importance of the liquidity risk premium, given stochastic transaction costs. Buss et al (2014) in a dynamic equilibrium model set up obtain only small price effects of transaction costs given consumption shocks. But Buss and Dumas (2013) show that transaction costs in presence of shocks to consumption provide for time variation in measures of liquidity, and this variation can be a priced factor.

We contribute to the literature by empirically analysing a stock market which has only one of these three properties. Around 1900, the Berlin Stock Exchange was not only Germany's leading stock market, but also a very liquid stock market with relatively small daily (and monthly) return fluctuations, located in a country that suffered recessions much more often than the modern day United States. This allows us localizing the need for consumption smoothing as the main driver of liquidity risk pricing. 
It is widely accepted that the Pre-World War I German stock market was on a high development stage: its relative weight in the economy, the stock market to GDP ratio, was higher than in contemporary United States (Rajan and Zingales 2003), it was quite informationally efficient (Gelman and Burhop 2008), providing for no arbitrage opportunities (Baltzer 2006). Stock market returns were also far less volatile than modern ones (Gelman and Burhop 2008), and transaction costs seemed to be comparable to the ones on the modern developed markets a century afterwards (Gehrig and Fohlin 2006). The substantially shorter business cycles in Imperial Germany are found and discussed in Burhop and Wolff (2005).

We use daily stock returns of a sample of 27 stocks, included into the index described in Gelman and Burhop (2008), to calculate the Lesmond, Ogden and Trczinka (1999, further LOT) indirect full transaction cost measure, which we utilize as the illiquidity proxy. ${ }^{1} \mathrm{We}$ provide evidence supportive of earlier findings of low transaction costs on the Berlin Stock Exchange. The LOT measure indicates that the cost for a roundtrip transaction (i.e., the sum of the costs of buyer and seller) was about 0.88 percent of the share price, slightly more than the 56 basis points found in Gehrig and Fohlin (2006) for the benchmark years 1890, 1900 and 1910. This compares to an estimate of 1.23 percent for the largest decile of firms listed at the New York Stock Exchange for the period 1963-1990 (Lesmond et al., 1999). Our data also allows corroborating findings in Amihud (2002) and Amihud and Mendelson (1986) in modern markets on the interrelations of illiquidity, returns and firm characteristics. Most importantly, we show that in line with our main hypothesis liquidity deteriorates after real economy shocks (GDP per capita declines) and during banking crises.

We run Fama-MacBeth (1973) regressions to estimate liquidity level and liquidity risk premia. We focus on the covariance of the asset's illiquidity with stock market returns as the liquidity risk channel. The premium for the illiquidity level becomes statistically insignificant when controlling for size, but we find a very high and significant illiquidity risk premium for our sample. Here, market, size (both as factor and characteristic), and momentum do not affect expected returns. The premium for taking the maximum illiquidity risk exposure amounts to 8.3 percent on an annual basis. It is several times higher than premiums reported for the modern US market (Acharya and Pedersen 2005) and exceeds substantially provided estimates for modern emerging markets (Lee 2011). We link such extraordinary influence of liquidity risk on expected returns on the Berlin Stock Exchange in 1892-1913 to more frequent recessions and events globally endangering the wealth of investors, such as banking crises (1891-1894, 1901 according to Reinhart and Rogoff (2010)). Both consumption

\footnotetext{
${ }^{1}$ The Berlin Stock Exchange has been a call-auction market and we can thus not use bid-ask-spreads as a proxy of liquidity. Turnover data on individual stocks are unavailable for the period under consideration.
} 
smoothing objectives and recovery from deposit losses would make market agents more willing to sell their stock assets. Given that such events were considered more probable than nowadays, the possibility of a quick and low cost liquidation of stock holdings was given a much higher value.

To support our argument we show that in our 22 year sample the liquidity risk premium was higher after real economy and banking sector shocks. We estimate the conditional liquidity risk premium, fitting multivariate GARCH-in-mean model to the series of excess market returns and aggregate market illiquidity, similar to Gibson and Mougeot $(2004)^{2}$ and Hagströmer et al. (2013). ${ }^{3}$ Our results strongly support the findings of the unconditional analysis: liquidity risk is significantly priced, whereas the market risk is not. Furthermore, we show that the impact of liquidity risk on expected excess returns is most pronounced after decreases in per capita real GDP growth and banking crises. In fact, past consumption shocks and shocks to the banking system explain about 3/4 of the time variation in liquidity premium in the conditional model. Thus, we strongly support findings that providing liquidity to the agents striving to smoothen their consumption or dampen the wealth shocks is rewarded by the market.

Thus, our main contribution to the financial economics literature is empirical support of the dependence of the liquidity risk premium on the business cycle. Whereas Watanabe and Watanabe (2008) show that there is an additional premium for higher illiquidity risk sensitivity in a high illiquidity risk regime, they do not establish a link between this regime and recessions or banking crises. While Jensen and Moorman (2010) show that expansionary monetary policy contributes to a higher illiquidity level premium, we focus on the illiquidity risk premium and show that the latter is realized in course of recovery from major real economy and banking system downturns. Finally, Hagströmer et al. (2013) state that the magnitude of illiquidity risk compensation is significantly higher in times of financial distress. We add to this by singling out business cycle caused financial market downturns. The remaining parts of the paper are organised as follows. In Section II we give a short overview of the theoretic links between the business cycle and liquidity and discuss in this respect the economic and financial environment in Imperial Germany. Section III provides description of

\footnotetext{
${ }^{2}$ As opposed to Gibson and Mougeot (2004), we use the LOT transaction costs measure for illiquidity rather than the changes in the standardized number of shares traded.

${ }^{3}$ This part of the study differs methodologically from Hagströmer et al. (2013) in several respects: first, we consider only the market portfolio (Hagströmer et al. 2013 considers an illiquidity risk mimicking portfolio as well). Second, we allow the risk premium for the covariance of return and illiquidity to be different from the premium for the market risk (variance). Thirdly, we use the LOT transaction costs measure (and proportion of zero returns in the robustness check) instead of the effective tick measure. Finally, we link the variation in the realized illiquidity risk premium to the business cycle variables.
} 
price fixing at the Berlin Stock Exchange at the turn of the $20^{\text {th }}$ century and presents our data sources. The augmented LOT measure of the round-trip transaction costs is illustrated in Section IV, along with a brief description of implemented econometric techniques. The results are presented in Section V, followed by a conclusion in Section VI. 


\section{Theoretical motivation and hypothesis}

The intuition behind our hypothesis that shorter business cycles, i. e. frequent real economic downturns, and bank crises, induce a higher liquidity risk premium can be best explained along the lines of the Lynch and Tan (2011) model.

In this model the investor is entitled to cash flows from the real economy (labour income) and has access to a high-liquidity and a low-liquidity portfolio, as well as a riskless asset. The agent has a power utility function with constant relative risk aversion. Her labour income is subject to stochastic shocks; there are stochastic shocks to the wealth as well. In the context of our study one can interpret a high-liquidity portfolio as deposits, low liquidity portfolio as stocks, and non-labour wealth shocks as bank crises, leading to partial deposit losses. The investor maximizes the utility of consumption over her life span. This objective leads to consumption smoothing behaviour. Moreover, the agent tends to keep optimal weights of the available asset types.

Thus, labour income shocks cause liquidity premia to increase, as the agent has to sell stocks and liquidate deposits to smoothen consumption. The impact of a shock to deposits is similar. The investor has to rebalance her portfolio selling stocks to keep up the desired optimal highliquidity portfolio weight (i.e., deposits). Thus, the occurrence of such shocks inflates the liquidity premium. Furthermore, Lynch and Tan (2011) show that the liquidity premium rises even further, if the transaction costs are countercyclical. They are higher in recessions, which is when the agent is the most motivated to trade. This change in the illiquidity premium constitutes the illiquidity risk premium. Extending this logic further, given the countercyclical behaviour of transaction costs, the illiquidity risk premium can be expected to be higher with a shorter average business cycle. The more often the recessions happen, the more frequent the investor faces the adverse reaction of transaction costs, when she is forced to trade. Thus she would value higher assets with less pronounced adverse behaviour, and the preference for such assets grows with the frequency of economic downturns.

Several stylized facts allow us to believe that analysing the illiquidity premium on the Berlin Stock Exchange around 1900 would provide better empirical support for the importance of business cycles than any existing literature.

One of the pre-World War I Imperial Germany distinguishing features are frequent recessions: in 1891-1913 Burhop and Wolff (2005) count five recessions, whereas for the modern day US - 1991-2013 - NBER counts only three. ${ }^{4}$ The average business cycle, measured from through to through, was thus twice shorter in Imperial Germany, about 52

\footnotetext{
${ }^{4}$ Note that the historical period directly precedes one of the strongest downturns of German economic history during World War I.
} 
months compared to 109.5 in the modern US. For these samples we observe 6 years of negative real GDP per capita growth in historical Germany opposed to 4 years in the US a century afterwards. Reinhart and Rogoff (2010) report five years of banking crises in German Empire over the sample, the same number as during the period of 1926-1947, covering the Great Depression in the US or in modern day Brazil (1989-2010).

Whereas real economy data signals very turbulent times, stock market data provides a completely different picture, showing a very peaceful state, which allows us separating the effect of business cycles from a competing stock market turbulence explanation. The standard deviation of monthly stock market index returns was with $2.1 \%$ twice smaller than 100 years later for Standard \& Poors 500 (4.5\%), four times smaller than for Standard and Poors 500 in the two decades covering the US Great Depression and World War II (8.2\%), and eight times smaller than the standard deviation of the dollar denominate Brazilian MSCI stock market index returns in 1988-2007 (16.5\%). Also the occurrence of extreme monthly stock returns, captured by kurtosis, was lower for the Berlin Stock Exchange market index than for modern day Standard \& Poors 500 (3.9 vs. 4.6), much lower than during the Great Depression (8.8), or in Brazil 1988-2007 (9.5).

The overall liquidity level seemed to be comparatively high: whereas Gehrig and Fohlin (2006) report the LOT measure for full transaction costs of about a half percentage point for the sample years 1890,1900 , and $1910^{5}$, Naes et al (2011, Table I, Panel A) obtain the same transaction cost measure for all US stocks in 1990 to 2008 of 3.35 percentage points. During the two decades embracing the Great Depression and the World War II Hagströmer et al. (2013, Fig. 1 (a)) observe effective tick measure of transaction costs of about 1.5-2 percentage points, which translates due to the downward bias of effective tick measure and upward bias of LOT into a LOT measure of approximately 7-9 percentage points. ${ }^{6}$ Illiquidity on an emerging stock market could be even more severe: Lesmond (2005) reports a LOT measure of 11.4 percentage points for the Brazilian stock market in 1991-2000. Another frequently used measure of illiquidity, the proportion of zero returns, also indicates that in terms of liquidity the Berlin stock exchange was close to what is observed in modern periods of solid and prosperous growth: we obtain $17.0 \%$ of zero return days for stocks in our sample, whereas Lee (2011) reports $16.4 \%$ for US stocks in $1988-2007$, as opposed to 29.0 over the same period in Brazil.

\footnotetext{
${ }^{5}$ We obtain slightly higher average transaction costs according to the LOT measure -88 basis points, see Section IV for details.

${ }^{6}$ Results of Goyenko et al. (2009) suggest that the ratio of LOT measure to effective tick measure is about 4.5
} 
Thus, our sample shares common macroeconomic features with states of the economy, which are known to produce a higher liquidity risk premium, but preserves the stock market features, liquidity and volatility, of a healthy and broad stock market, which are usually associated with a lower liquidity risk premium.

Another advantage of the German stock market in the Wilhelmian era is the predominance of private investors. In the period 1892-1913 institutional investors were merely present on the market (Franks et al., 2006: 571, Liefmann, 1923: 191-195). This allows us to interpret the result in the spirit of models like Lynch and Tan (2011), without adjusting for possible effects of changes in institutional holdings. 


\section{Stock Market Structure and Data Description}

Shares were traded at the Berlin Stock Exchange six days per week using a call auction mechanism. Prices were fixed once a day by official, government appointed brokers. The brokers' association allocated two official brokers to each stock listed at the exchange. They jointly fixed the official price of the share and they both had the duty to act as brokers for the stock, i.e. they could not decline to take orders. They started taking orders at noon and stopped taking orders not earlier than 1.30 p.m. and not later than 2 p.m. Orders were made orally by representatives of banks and other participants on the trading floor. The official broker orally repeated the order and his substitute recorded the order into the order book. The order book was arranged in four columns, one for unlimited buying orders, one for limited buying orders, one for unlimited selling orders, and one for limited selling orders. The official price had to reflect the true commerce at the stock exchange. At the official price, it had to be possible that all unlimited buy and sell orders as well as buy orders with a higher price limit and sell orders with a lower price limit were carried out. Whenever the official broker expected a major price change (i.e., a price change of more than one percent), he had to make a written announcement to the trading floor. Moreover, in this case, a state commissioner joined the two official brokers to monitor the price fixing. The first tentative price was prepared in public and all interested parties could attend this event. Moreover, it was still possible to place further orders or to cancel formerly made orders. Afterwards, the two official brokers went to the back office, where the official quotation was registered, signed by the state commissioner, and published in the official price list (Obst, 1921: 380, 386-392).

Some information on the number of trades and trade size can be obtained from the Berlin clearing facility Kassenverein, which provided clearing and settlement for some set of stocks and bonds throughout the period under study. ${ }^{7}$ Kassenverein annual reports presented annual trading volume handled and the number of handled transactions per year. The average transaction size in 1892-1913 was about 29.7 thousand mark (about 1.5 million euro in prices of 2013), and in 1899 there were about 6.4 transactions per stock per day on average.

Turning to transaction costs, we can distinguish three types of observable costs: taxes, broker fees, and bank fees. Transactions at German stock exchanges were taxed from 1881 onwards. More specifically for the period under consideration here, the stock market turnover tax was 0.01 percent of the underlying transaction value between 1892 and April 1894. From May 1894 onwards, the tax was doubled to 0.02 percent; another increase to 0.03 percent followed

\footnotetext{
${ }^{7}$ Kassenverein was founded in 1882 and functioned until 1943. We have only fragmental information on its operations. E. g., we know that the subset of securities eligible for clearing as of 1899 included 127 stocks and bonds, but unfortunately we do not have the list of those companies.
} 
in October 1900. In addition to turnover taxes, the fees for brokers influence transaction costs. The fee for official brokers was 0.05 percent of the underlying transaction value (Gelman and Burhop, 2008). Furthermore, fees for the banks or other intermediaries varied between 0.1 and 0.33 percent (Weigt, 2005: 192). Thereunder the clearing fee, if the transaction was settled over the Kassenverein, amounted 0.1 percent capped at 5 Mark. Taking into account the average transaction size, usually the cap fee was paid, which was on average only 0.02 percent of the transaction value. In sum, broker fees, fees for intermediaries, and turnover taxes added up to a total cost for a roundtrip transaction (i.e., buying and selling of a share) in the range of 0.28 to 0.76 percent. $^{8}$

To investigate the size of actual transaction costs and to evaluate whether they changed over time, we use daily stock prices for the period 31 December 1891 to 31 December 1913 collected from the Berliner Börsenzeitung - Germany's leading financial daily of the pre1913 period - for a sample of 27 continuously traded corporations from the Berlin stock exchange. The data were obtained from Gelman and Burhop (2008) who construct a daily stock market index for the period 1892-1913. ${ }^{9}$ The sample contains 6,692 daily returns. Descriptive statistics of individual stocks are shown in Table 1. The average daily return of an individual stock was about 2 basis points (5.2\% annualized) and the average standard deviation with 74 basis points was about a half of the modern stock return volatility, but corresponds to the values reported by Gehrig and Fohlin $(2006: 10,12)$ for 1890, 1900 and 1910. Most of the stock returns are negatively skewed; all of them are leptokurtic, somewhat stronger than the modern day stock returns.

To make some statements in how far our sample is representative for the whole universe of stocks traded on the Berlin stock exchange, we compare the size of selected companies to the full cross-section in 1900 (the only data available to us for all listed stocks). From 826 listed companies there is market capitalization data only for 764 companies. ${ }^{10}$ The aggregate market capitalization of our sample accounts for 16 percent of the total market capitalization. The average capitalization of all listed stocks with reported data was with 1.1 million Mark about five times smaller than the average capitalization of the selected 27 companies, which amounted to 5.2 million in 1900. Both a simple t-test of the mean as well as a non-parametric

\footnotetext{
${ }^{8}$ Tick size, which could have relevance for price impact, was 0.05 percent of face value (of typically 1,000 Mark).

9 Starting point for the index construction was the collection of daily share prices from the Berliner Börsenzeitung for a sample of 39 continuously listed non-insurance corporations from the Berlin stock exchange. Insurance companies were excluded from the index since trading in them was heavily restricted. They only issued vinkulierte Namensaktien, registered shares with restricted transferability. Then securities with the portion of zero daily returns in the period under study of one third or higher were deleted from the index. 27 corporations remained.

${ }^{10}$ Details are available on demand.
} 
Mann-Whitney test indicate that our sample is biased towards larger stock. In fact, the average size rank (ordered descending) of our sample stocks is 170.1 compared to the expected 382.5 ; 5 out of the 10 largest companies listed on the exchange belong to the sample. 
Table 1. Distributional properties of daily stock returns of the Gelman-Burhop-index constituent companies

\begin{tabular}{|c|c|c|c|c|c|c|c|c|c|c|c|c|}
\hline & Name & $\begin{array}{l}\text { Mean } \\
\text { (ann.) }\end{array}$ & $\begin{array}{l}\text { Median } \\
\text { (ann.) }\end{array}$ & Max. & Min. & $\begin{array}{l}\text { Std. } \\
\text { Dev. }\end{array}$ & $\begin{array}{l}\text { Skew- } \\
\text { ness }\end{array}$ & Kurtosis & $\begin{array}{l}\text { Proportion } \\
\text { of zero } \\
\text { returns }\end{array}$ & $\begin{array}{l}\text { HQ in } \\
\text { Berlin }\end{array}$ & $\rho(1)$ & $\begin{array}{l}\text { Average } \\
\text { market } \\
\text { cap } \\
(1,000 \\
M)\end{array}$ \\
\hline 1 & AG für & & & & - & & & & & & & \\
\hline 2 & $\begin{array}{l}\text { Anilinfabrikation } \\
\text { Alloemeine }\end{array}$ & 0.1162 & 0.0000 & 0.1257 & 0.1509 & 0.0073 & -0.09 & 51.12 & 0.1634 & Y & 0.0034 & 27,265 \\
\hline & Elektricitätsgesellschaft & 0.0598 & 0.0000 & 0.0526 & 0.0789 & 0.0063 & 0.09 & 12.92 & 0.0811 & Y & $0.0907^{*}$ & 149,966 \\
\hline 3 & $\begin{array}{l}\text { Berlın-Anhaltınısche } \\
\text { Maschinenbau }\end{array}$ & 0.0521 & 0.0000 & 0.1037 & 0.0878 & 0.0074 & 0.15 & 23.71 & 0.1559 & Y & $0.0454^{-}$ & 11,793 \\
\hline 4 & $\begin{array}{l}\text { Bochumer Bergwerk } \\
\text { (Lit C) }\end{array}$ & -0.0208 & 0.0000 & 0.4347 & 0.1956 & 0.0184 & 2.06 & 62.90 & 0.2193 & $\mathrm{~N}$ & 0.0208 & 3,510 \\
\hline 5 & $\begin{array}{l}\text { Darmstädter Bank } \\
\text { (BHI) }\end{array}$ & 0.0192 & 0.0000 & 0.0642 & $0.0846^{-}$ & 0.0041 & -0.68 & 43.48 & 0.1917 & $\mathrm{~N}$ & -0.0227 & 327,785 \\
\hline 6 & Deutsche Bank & 0.0527 & 0.0000 & 0.0323 & $\begin{array}{r}- \\
0.0701\end{array}$ & 0.0037 & -0.97 & 28.00 & 0.1004 & Y & 0.0017 & 199,308 \\
\hline 8 & $\begin{array}{l}\text { Dresdner Bank } \\
\text { Deutsche Jute }\end{array}$ & 0.0281 & 0.0000 & 0.0446 & $\begin{array}{r}0.0765 \\
-\end{array}$ & 0.0046 & -0.99 & 24.74 & 0.1062 & $\mathrm{Y}$ & $0.0304 *$ & 166,892 \\
\hline 9 & Spinnerei und Weberei & 0.0763 & 0.0000 & 0.0674 & $\begin{array}{r}0.0637 \\
-\end{array}$ & 0.0076 & 0.12 & 12.32 & 0.2057 & $\mathrm{~N}$ & 0.0080 & 4,301 \\
\hline 10 & $\begin{array}{l}\text { Deutsche Spiegelglas } \\
\text { Erdmannsdorfer }\end{array}$ & 0.0926 & 0.0000 & 0.0921 & 0.0838 & 0.0076 & 0.24 & 16.25 & 0.1873 & $\mathrm{~N}$ & $0.0813^{*}$ & 6,430 \\
\hline 11 & $\begin{array}{l}\text { Spinnerei } \\
\text { Gelsenkirchener }\end{array}$ & -0.0243 & 0.0000 & 0.0909 & 0.0774 & 0.0102 & 0.13 & 9.82 & 0.2516 & $\mathrm{~N}$ & $0.0382 *$ & 2,861 \\
\hline 12 & $\begin{array}{l}\text { Bergwerksgesellschaft } \\
\text { Gerresheimer }\end{array}$ & 0.0435 & 0.0000 & 0.0484 & 0.0843 & 0.0069 & -0.63 & 12.78 & 0.0553 & $\mathrm{~N}$ & $0.0296^{*}$ & 155,797 \\
\hline & Glashütten & 0.0803 & 0.0000 & 0.0739 & 0.1208 & 0.0075 & -1.14 & 33.53 & 0.2468 & $\mathrm{~N}$ & $0.0596 *$ & 11,118 \\
\hline
\end{tabular}




\begin{tabular}{|c|c|c|c|c|c|c|c|c|c|c|c|}
\hline 13 Hallesche & & & & & & & & & & & \\
\hline Maschinenfabriken & 0.0785 & 0.0000 & 0.1000 & 0.2788 & 0.0087 & -6.32 & 213.59 & 0.1701 & $\mathrm{~N}$ & -0.0222 & 6,666 \\
\hline & & & & - & & & & & & & \\
\hline Harpener Bergbau AG & 0.0418 & 0.0000 & 0.0668 & 0.0536 & 0.0072 & 0.08 & 9.43 & 0.0520 & $\mathrm{~N}$ & $0.0293 *$ & 104,004 \\
\hline Kattowitzer AG für & & & & - & & & & & & & \\
\hline Bergbau und Eisen & 0.0693 & 0.0000 & 0.0609 & 0.0493 & 0.0064 & 0.39 & 11.63 & 0.1322 & $\mathrm{~N}$ & $0.0499 *$ & 46,517 \\
\hline Maschinenfabrik & & & & - & & & & & & & \\
\hline Kappel & 0.1228 & 0.0000 & 0.2014 & 0.1107 & 0.0106 & 0.96 & 34.81 & 0.1716 & $\mathrm{~N}$ & $0.0812 *$ & 3,401 \\
\hline Norddeutsche & & & & & & & & & & & \\
\hline Wollkämmerei & 0.0414 & 0.0000 & 0.0738 & 0.0838 & 0.0077 & 0.37 & 14.24 & 0.2028 & $\mathrm{~N}$ & $0.0315^{*}$ & 19,260 \\
\hline Oberschlesische & & & & - & & & & & & - & \\
\hline Portland-Cement AG & 0.0500 & 0.0000 & 0.1267 & 0.0943 & 0.0095 & 0.86 & 23.96 & 0.1546 & $\mathrm{~N}$ & $0.0261 *$ & 4,397 \\
\hline & & & & - & & & & & & - & \\
\hline Rheinische Stahlwerke & 0.0487 & 0.0000 & 0.1095 & 0.1427 & 0.0081 & -0.21 & 41.19 & 0.1230 & $\mathrm{~N}$ & $0.0337 *$ & 37,447 \\
\hline Rositzer Zuckerfabrik & 0.0576 & 0.0000 & 0.0833 & 0.0826 & 0.0091 & 0.13 & 11.93 & 0.1414 & $\mathrm{~N}$ & 0.0240 & 7,167 \\
\hline Schaffhausen'scher & & & & ג0277 & 00025 & 0 & 1036 & 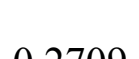 & & $*$ & \\
\hline $\begin{array}{l}\text { Bankverein } \\
\text { Chemische Fabrik }\end{array}$ & 0.0104 & 0.0000 & 0.0454 & $\begin{array}{r}0.0377 \\
-\end{array}$ & 0.0035 & 0.43 & 19.36 & 0.2709 & $\mathrm{~N}$ & $0.1212^{*}$ & 140,431 \\
\hline vormals Schering & 0.0468 & 0.0000 & 0.0652 & 0.0561 & 0.0080 & 0.48 & 9.41 & 0.1637 & $\mathrm{Y}$ & $0.0640 *$ & 12,983 \\
\hline & & & & - & & & & & & - & \\
\hline Schlesische Zinkhütten & 0.0607 & 0.0000 & 0.1079 & 0.0847 & 0.0062 & 0.42 & 31.36 & 0.2411 & $\mathrm{~N}$ & $0.0579 *$ & 79,468 \\
\hline Schlesische Leinen- & & & & - & & & & & & - & \\
\hline Industrie & 0.0140 & 0.0000 & 0.0703 & 0.0679 & 0.0061 & -0.35 & 21.76 & 0.3191 & $\mathrm{~N}$ & $0.1578 *$ & 10,154 \\
\hline & & & & - & & & & & & 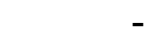 & \\
\hline Schultheiss Brauerei & 0.0569 & 0.0000 & 0.0897 & 0.0853 & 0.0051 & 0.67 & 82.49 & 0.1717 & $\mathrm{Y}$ & $0.2288^{*}$ & 25,224 \\
\hline & 70 & ( $\cap \Omega \cap \Omega$ & 00420 & 00450 & 00052 & 0 & 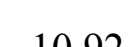 & 4 & $T$ & 20 & \\
\hline $\begin{array}{l}\text { Siemens Gias-Inaustrie } \\
\text { Stettiner }\end{array}$ & $0.00 / 9$ & 0.0000 & 0.0438 & 0.0439 & 0.0053 & 0.50 & 10.92 & 0.1904 & $Y$ & -0.0239 & 22,890 \\
\hline Chamottewaren & 0.0527 & 0.0000 & 0.0804 & 0.0696 & 0.0076 & 0.73 & 18.37 & 0.1451 & $\mathrm{~N}$ & 0.0872 & 26,403 \\
\hline Average & 0.0517 & 0.0000 & 0.0947 & $0.0932^{-}$ & 0.0074 & -0.10 & 32.82 & 0.1711 & & 0.0014 & 59,757 \\
\hline
\end{tabular}




\begin{tabular}{ccccccccccc} 
& & & - & & & & \\
Median & 0.0527 & 0.0000 & 0.0739 & 0.0838 & 0.0074 & 0.13 & 21.76 & 0.1701 & 0.0080 \\
\hline Gelman-Burhop index & 0.0687 & 0.0909 & 0.0296 & 0.0562 & 0.0032 & -1.68 & 30.78 & $\mathrm{n} / \mathrm{a}$ & $0.165^{*}$ & $1,613,445$ \\
\hline
\end{tabular}

Notes: The table contains descriptive statistics for daily stocks returns, measured as percentage stock price changes. Days with mandatory dividend and actual dividend corrections are dropped (1-2 days per company per year). Mean and median returns are presented on the annual basis (location measure $\mathrm{x} 300$ ) for illustrative purposes.

* denotes significance of the autocorrelation coefficient on the 5 percent level. 
Although our sample is skewed towards larger companies it spans a wide range of stocks in terms of size, from the largest (Deutsche Bank) to those ranked $590^{\text {th }}$ and $495^{\text {th }}$ from the top (Bochumer Bergwerk and Erdmannsdorfer Spinnerei correspondingly). The difference in distribution of logged market capitalization (which is supposed to stay in linear relationship with liquidity, see Gehrig and Fohlin (2006) and Section IV) is by far not that striking, with averages of 19.9 and 21.4 for 764 stocks and our sample respectively. The scope of zero returns seems also to be adequate: it ranges from 5 percent of trading days for Harpener Bergbau to 32 percent of trading days for Schlesische Leinen, with an average of 17 percent or approximately 51 days per year (see Table 1). This is slightly less than 22 percent reported by Gehrig and Fohlin (2006) for their sample of 114 stocks from the Berlin stock exchange in 1900. Hence, our sample can be regarded as representative of stocks traded on the Berlin Stock Exchange at the turn of the $20^{\text {th }}$ century except for a small bias towards larger and more liquid stocks.

A remarkable feature of these historic returns is a rather low volatility: only $0.7 \%$ on the daily basis (see Table 1), which is about one third of the standard deviation of modern S\&P 500 constituents' daily returns (Barclay et al. 2008, Table 1). Another notable feature of Berlin Stock Exchange returns is their high kurtosis. Median kurtosis of daily stock returns of our companies is 21.8, being almost double of the median kurtosis of S\&P 500 (12.8), measured over 1990-2011. This difference is significant according to a Mann-Whitney test on any conventional level. 131 companies in the S\&P 500 index have thinner tails than the most slender-tailed stock return distribution in our historical sample (that of Schering Chemische Fabrik).

The dynamic properties indicate that active liquidity provision is possible: For eight stocks we report a significant negative daily return autocorrelation.

Beyond the reported properties of stock prices we have also obtained dividend data taken from the Berliner Börsenzeitung. Data on aggregate annual trade volume of all securities in Imperial Germany can serve as a proxy of the overall trading activity (obtained from Wetzel 1996). The aggregate trade volume time series behaves stationary with the approximately same value of securities traded in 1913 as in 1892 (see Appendix 8).

\section{LOT measure and econometric technique}

In an information-efficient stock market, prices of stocks should incorporate new information instantaneously. On the real-world stock exchanges, however, the presence of transaction 
costs induces some deviations from such behaviour. Uncovering these deviations and analyzing them allows tracking back full transaction costs.

This idea is exploited in a measure of transaction costs, proposed by Lesmond et al. (1999). The LOT measure reflects the total costs of a roundtrip transaction, which includes not only the difference between bid and ask prices, but also all further expenses carried by the trader, including the price change induced by the trade itself (so called price impact, see Lesmond 2005). The LOT measure is based on the idea that transactions will only occur if the deviation of the market price from the true value of a stock is larger than the costs of a transaction. Thus, there are upper and lower thresholds $-i_{i}$ and $i^{h}-$ such that the measured return $r$ is non-zero only if the true return exceeds the threshold:

$$
\begin{aligned}
& \text { (4a) } r_{i, t}=r_{i t}^{*}-\tau_{i}^{1} \text { if } r_{i, t}^{*}<\tau_{i}^{1} \\
& \text { (4b) } r_{i, t}=0 \text { if } \tau_{i}^{1}<r_{i, t}^{*}<\tau_{i}^{h} \\
& \text { (4c) } r_{i, t}=r_{i t}^{*}-\tau_{i}^{h} \text { if } r_{i, t}^{*}>\tau_{i}^{h} .
\end{aligned}
$$

The true return depends on the market return $r_{m, t}$ in a linear way: $r_{i, t}^{*}={ }_{i} r_{m, t}+e_{i, t}$.

The estimated difference between the upper and the lower threshold - i.e. ${ }_{i}^{h}$ less $i^{1}-$ is a measure of the roundtrip transaction costs: $S_{i}=\tau_{i}^{h}-\tau_{i}^{l}$.

We use the following maximum likelihood estimator, developed by Lesmond et al. (1999), to estimate the LOT measure:

$$
\begin{aligned}
& \quad L\left(\tau_{i}^{l}, \tau_{i}^{h}, \beta_{i}, \sigma_{i} \mid r_{i t}, r_{m t}\right)=\prod_{1} \frac{1}{\sigma_{i}} \phi\left[\frac{r_{i t}+\tau_{i}^{l}-\beta_{i} r_{m t}}{\sigma_{i}}\right] \times \prod_{0}\left[\Phi\left(\frac{\tau_{i}^{h}-\beta_{i} r_{m t}}{\sigma_{i}}\right)-\Phi\left(\frac{\tau_{i}^{l}-\beta_{i} r_{m t}}{\sigma_{i}}\right)\right] \\
& (5) \times \prod_{2} \frac{1}{\sigma_{i}} \phi\left[\frac{r_{i t}+\tau_{i}^{h}-\beta_{i} r_{m t}}{\sigma_{i}}\right] \\
& \text { S.T. } \tau_{i}^{l} \leq 0, \tau_{i}^{h} \geq 0, \beta_{i} \geq 0, \sigma_{i} \geq 0,
\end{aligned}
$$

Where $\Phi()$ is the standard normal cumulative distribution function. Region 1 (indicated by the subscript " 1 " of ) corresponds to the negative expected latent variable when the observed is nonzero $\left(\hat{r}_{i t}^{*}<0\right.$, or equivalently $r_{m t}<0$ and $\left.r_{i t} \neq 0\right)$, region 2 to the positive expected latent variable if the observed is nonzero $\left(r_{m t}>0\right.$ and $\left.r_{i t} \neq 0\right)$, and region 0 corresponds to the observation with zero observed returns $\left(r_{i t}=0\right) . \sigma_{i}$ denotes the root out of the residual variance, measured over the non-zero returns region. 
The LOT measure thus includes the bid-ask spread, fees, transaction taxes, costs of information acquirement and processing, as well as price impact. Its size should be therefore larger than the regulated costs, i.e., the sum of broker fees, provisions, and transaction taxes. We calculate this measure for each company and each year, and then provide also aggregated estimates across companies and years.

To illustrate the dynamic and cross-sectional properties of liquidity we run a panel regression:

$$
\text { (10) } S_{i t}=\alpha+\beta^{\prime} X_{i t}+\mu_{i}+\lambda_{t}+v_{i t}
$$

where $X$ denotes a vector of explanatory variables, $\beta$ a vector of corresponding coefficients, $\mu_{i}$ denotes cross-sectional individual effects, $\lambda_{t}$ denotes year effects and $v_{i t}$ is an idiosyncratic error term.

To test for relevance of liquidity level and liquidity risk for asset pricing we run time series regressions of illiquidity- and liquidity risk-sorted portfolios on commonly used factors of the type:

$$
\text { (11) } R_{p t}=\alpha_{p}+\boldsymbol{\beta}_{p}^{\prime} \boldsymbol{F}_{t}+\varepsilon_{p, t} \text {, }
$$

where $R_{p t}$ denotes excess return on a test portfolio $p, \boldsymbol{F}_{\boldsymbol{t}}$ represents the vector of realizations of factor-mimicking portfolio returns. We test for individual and joint significance of intercepts $\alpha_{p}$. Whereas we use standard $t$-test for individual significance, we apply Gibbons et al. (1989, GRS) test for joint significance of pricing errors:

$$
J_{1}=\frac{T-N-K}{N}\left[1+\hat{\mu}^{\prime} \Omega^{-1} \hat{\mu}\right]^{-1} \hat{\alpha} \hat{\Sigma}^{-1} \hat{\alpha}
$$

Where $T$ is the length of the sample, $N$ - number of test portfolios involved, $K$ - number of factors, $\hat{\mu}$ is the vector of average factor returns, $\Omega$ denotes the variance-covariance matrix of factor portfolio returns, and $\hat{\Sigma}$ is the variance-covariance matrix of residuals from Eq. 11 . The test-statistic under the null of no pricing errors is distributed according to the Fdistribution with $N$ and $T-N-K$ degrees of freedom. Rejection of the null in this setup is in favour of the impact of liquidity on asset pricing.

For estimation of liquidity level and liquidity risk premiums in unconditional asset pricing models we rely on the standard technique in the asset pricing literature, the Fama-MacBeth (1973) regression. It is based on the assumption that expected returns of stocks are fully described by the linear combination of risk premia and factor loadings for all relevant factors:

$$
E\left[Z_{i}\right]=\lambda^{\prime} B_{i}
$$

whereby $Z_{i t}=r_{i t}-r_{f t}$ denotes excess return, $\lambda^{\prime}$ is a transposed vector of risk-premia, and $B_{i}$ is a vector of factor loadings or risk characteristics of company $i$. Given the values of factor 
loadings for each stock in each period the risk premia are estimated running $T$ cross-section regressions (one for each period) and averaging the estimates:

$$
\begin{gathered}
Z_{i t}=\lambda_{t}^{\prime} B_{i t} \\
\bar{\lambda}=\frac{1}{T} \sum_{t=1}^{T} \hat{\lambda}_{t} .
\end{gathered}
$$

The corresponding standard errors for each $k$-th element of the risk-premia vector are calculated from the corrected time variance of the estimated premia:

$$
\begin{gathered}
\operatorname{var}\left[\lambda_{k t}\right]=\frac{1}{T} \sum_{t=1}^{T}\left(\hat{\lambda}_{k t}-\bar{\lambda}_{k}\right)^{2} \\
\operatorname{stderr}\left[\bar{\lambda}_{k}\right]=\sqrt{\operatorname{var}\left[\lambda_{k t}\right] \cdot\left(1+\bar{\lambda}^{\prime} \Omega^{-1} \bar{\lambda}\right) / T},
\end{gathered}
$$

where $\Omega$ denotes the variance-covariance matrix of factor portfolio returns. For the risk factor $k$ to be priced the corresponding risk premium should be significantly different from zero.

To obtain the illiquidity risk factor loadings $\beta_{i}^{I L}$ we calculate the sensitivity of unpredicted transaction costs to market movements using the following linear regression:

$$
\tilde{s}_{i t}=\omega+\beta_{i}^{I L} \cdot r_{m t}+u_{i t} \text {. }
$$

Unpredicted illiquidity is defined as the residual from a second order panel vectorautoregression of transaction costs and annual stock returns (without dividends):

$$
X_{i t}=A_{0}+A_{1} X_{i t-1}+A_{2} X_{i t-2}+C z_{i t-1}+U_{i t},
$$

where $X_{i t}=\left(\begin{array}{c}r_{i t} \\ s_{i t}\end{array}\right)$ is the vector of dependent variables and $U_{i t}=\left(\begin{array}{c}\varepsilon_{i t}^{r} \\ \tilde{s}_{i t}\end{array}\right)$ the residual vector;

$z_{i t}$ denotes the fraction of the market capitalisation of the company in the aggregate market capitalisation. $A_{0}$ and $C$ are vectors and $A_{1}$ and $A_{2}$ matrices of coefficients which are kept invariable across companies.

Methods involved in estimation of conditional liquidity risk premiums are discussed in Subsection IV.3.3.

\section{Results}

\section{Estimated transaction costs}

Table 2 presents the averages across all shares of LOT measures of round trip transaction costs as well as the average for the full sample period 1892-1913. The transaction costs at the Berlin Stock Exchange varied between 0.56 percent (in 1906) and 1.58 percent (in 1901). The transaction costs were positive for any randomly chosen yearly period and they were always 
higher than the lower bound of the regulated fees. The average transaction costs amounted to 0.88 percent. Therefore, we broadly confirm the result presented by Gehrig and Fohlin (2006), who estimated an average LOT measure of 0.71 percent for the four benchmark years 1880 , 1890, 1900, and 1910 .

Table 2. Dynamics of illiquidity: annual averages.

\begin{tabular}{ll} 
Year & LOT \\
\hline 1892 & 1.415 \\
1893 & 1.520 \\
1894 & 1.011 \\
1895 & 0.867 \\
1896 & 0.755 \\
1897 & 0.748 \\
1898 & 0.792 \\
1899 & 0.789 \\
1900 & 0.913 \\
1901 & 1.579 \\
1902 & 0.910 \\
1903 & 0.786 \\
1904 & 0.728 \\
1905 & 0.626 \\
1906 & 0.563 \\
1907 & 0.693 \\
1908 & 0.705 \\
1909 & 0.642 \\
1910 & 0.975 \\
1911 & 0.635 \\
1912 & 0.779 \\
1913 & 0.971 \\
Average & 0.882 \\
\hline
\end{tabular}

It may come as a surprise that transaction costs were quite low compared to the modern exchanges. Næs et al. (2011) report LOT measure average of 2.7 percent for NYSE listed stocks in 2000-2008, which is 3.5 times larger than transaction costs for our subsample a century earlier. The average LOT measure for NYSE listed stocks in troubled 1970-s was much higher: 5.1\%, according to Næs et al. (2011). Even taking the most liquid US-stocks as a benchmark presents the liquidity on the Berlin Stock Exchange around 1900 in a favourable light: Goyenko et al. (2009) document LOT measures for the Dow Jones Industrial Average 
index of 0.6 percent for the mid 1970s and 1980s which is comparable to our results for the Berlin Stock Exchange index in mid 1900s. Evidence for other modern stock markets supports the impression that transaction costs were quite low at the Berlin Stock Exchange a century ago. Very advantageous is the comparison to the modern emerging markets: Stocks in the Gelman-Burhop (2008) index have lower transaction costs according to the LOT measure than any of the 31 emerging markets in the 1990s, covered in the study of Lesmond (2005). Their average transaction costs range from 2.3 percent for Taiwan to 18 percent for Russia. Transaction costs varied across companies (see Appendix 1). Whereas textile companies, such as Deutsche Jute Spinnerei und Weberei and Erdmannsdorfer Spinnerei report augmented LOT measures of 0.98 percent and 1.50 percent - which could be found also for median modern Chinese stock (Lesmond, 2005) - the transaction costs of banking sector stocks like Deutsche Bank (0.23 percent) and Dresdner Bank (0.28 percent) is on the same level with Dow Jones companies in the 1980s and 1990s (Goyenko et al., 2009). These deviations, however, cannot be attributed fully to industry differences: companies included into the index stemming from the banking sector have a much higher market capitalization, e.g., the value of Deutsche Bank was on average 114 times the value of Erdmannsdorfer Spinnerei. 


\section{Explaining liquidity}

In this subsection we show that illiquidity dynamics and cross sectional variation is in line with findings on modern market and earlier studies of historical markets and highlight some peculiarities of the Berlin Stock Exchange pre-WWI.

Illiquidity is known to be negatively related to past stock returns (Amihud 2002, Bekaert 2007) and current trading activity. Furthermore, liquidity deteriorates in times of real economy shocks (Hagströmer et al. 2013).

Illiquidity variation across stocks is usually tied to the size of companies (Amihud 2002, Gehrig and Fohlin 2006) and the location of the company headquarters (Loughran and Schultz 2005, Shive 2012, Jacobs and Weber 2012).

We use annual individual stock returns and include the aggregate annual trade volume of all securities in Imperial Germany per year to proxy trading activity. ${ }^{11}$ In order to reflect crises we use real GDP per capita growth and banking crisis year dummies, defined by Reinhart and Rogoff (2010).

Our size variable is the fraction of the overall market capitalization contributed by each company, whereby using fraction instead of absolute or log values allows us to circumvent non-stationarity problems. Location is implemented as a dummy, taking value 1 if company's headquarters are in Berlin and 0 else. We further include daily return autocorrelation in the regression. Full description of explanatory variables involved is given in Appendix 2.

To test our hypotheses we run balanced panel regressions with individual effects. All explanatory variables, but size and banking crisis dummy are lagged one period to avoid possible reverse causality. We do not lag the size variable, as market capitalization is reported at the beginning of the year (January 2), and thus is predetermined with respect to our transaction cost measure in the same year. We use a contemporaneous banking crisis variable since, according to the stylized model, deposit losses would require instantaneous rebalancing of savings, i.e. sales of stocks. Since our proximity dummy, company headquarters' location in Berlin, does not change over time, we apply a random effects specification. ${ }^{12}$ As transaction costs are believed to be rather persistent (Bekaert et al. 2007, Amihud 2002), we use White period standard errors, which account for clustering by stocks.

\footnotetext{
${ }^{11}$ Unfortunately, trade volumes of individual stocks are unavailable at any frequency.

${ }^{12}$ Hausman test for the base specification, column 1 in Table 3 after omitting the location dummy, aggregate trading volume and period effects suggests using random effects. If one omits the location dummy from a full specification (column 5) or from the specification in column 3 and runs a Hausman test, the variance-covariance matrix of the coefficient differences in both cases becomes non-positive definite, so that it is impossible to appropriately calculate the joint test statistics. However, all individual estimate differences are insignificant, so that the models are likely to provide the same coefficients. Hence, even in the absence of location dummy using random effects is preferable.
} 
Table 3: Panel regression: determinants of illiquidity

\begin{tabular}{|c|c|c|c|c|c|}
\hline & (1) & (2) & (3) & (4) & (5) \\
\hline \multirow[t]{2}{*}{ Constant } & $0.0178 * * *$ & $0.0178 * * *$ & $0.0101 * * *$ & $0.0100 * * *$ & $0.0103 * * *$ \\
\hline & $(0.0058)$ & $(0.0059)$ & $(0.0028)$ & $(0.0029)$ & $(0.0017)$ \\
\hline \multirow[t]{3}{*}{$M C_{i t} / \sum M C_{i t}$} & - & - & - & - & - \\
\hline & $0.0468 * * *$ & $0.0468 * * *$ & $0.0468 * * *$ & $0.0467 * * *$ & $0.0468 * * *$ \\
\hline & $(0.0076)$ & $(0.0076)$ & $(0.0079)$ & $(0.0078)$ & $(0.0080)$ \\
\hline \multirow{3}{*}{$X R_{i t-1}$} & - & $-0.0036^{* *}$ & $-0.0033 * *$ & $-0.0032 * *$ & $-0.0025^{*}$ \\
\hline & $0.0037 * * *$ & $(0.0014)$ & $(0.0013)$ & $(0.0014)$ & $(0.0014)$ \\
\hline & $(0.0014)$ & & & & \\
\hline \multirow{2}{*}{$\ln T V_{t}$} & -0.0018 & -0.0018 & -0.0000 & -0.0000 & -0.0001 \\
\hline & $(0.0013)$ & $(0.0013)$ & $(0.0007)$ & $(0.0007)$ & $(0.0004)$ \\
\hline \multirow[t]{2}{*}{$H Q_{i}$ in Berlin } & $-0.0014 * *$ & $-0.0014 * *$ & $-0.0014 * *$ & $-0.0014 * *$ & $-0.0014 * *$ \\
\hline & $(0.0007)$ & $(0.0007)$ & $(0.0007)$ & $(0.0007)$ & $(0.0007)$ \\
\hline \multirow{2}{*}{$\rho_{i t-1}^{1}$} & & -0.0010 & & -0.0012 & -0.0019 \\
\hline & & $(0.0013)$ & & $(0.0012)$ & $(0.0012)$ \\
\hline \multirow[t]{2}{*}{${\text { Bank } \text { Crisis }_{t}}$} & & & $0.0042 * *$ & $0.0042 * *$ & $0.0043 * * *$ \\
\hline & & & $(0.0017)$ & $(0.0017)$ & $(0.0009)$ \\
\hline GDP p.c. & & & $-0.0232 * *$ & $-0.0236^{*}$ & - \\
\hline \multirow[t]{2}{*}{ growth $_{t-1}$} & & & $(0.0117)$ & $(0.0120)$ & $0.0240 * * *$ \\
\hline & & & & & $(0.0063)$ \\
\hline Time effects & $\mathrm{RE}$ & $\mathrm{RE}$ & $\mathrm{RE}$ & $\mathrm{RE}$ & - \\
\hline Firm effects & $\mathrm{RE}$ & $\mathrm{RE}$ & $\mathrm{RE}$ & $\mathrm{RE}$ & $\mathrm{RE}$ \\
\hline$R^{2}$ & 0.31 & 0.31 & 0.38 & 0.38 & 0.39 \\
\hline
\end{tabular}

Estimates of LS individual effects models for the transaction costs (LOT measures) for the sample period from 1892 to 1913 for the panel of 26 companies $^{13}$ of the type: $S_{i t}=\alpha+\beta^{\prime} X_{i t}+\mu_{i}\left(+\lambda_{t}\right)+v_{i t} . M C_{i t} / \sum M C_{i t}$ denotes the fraction of the company $i$ in the total market capitalisation of all considered firms in year $t, X R_{i t}$ denotes return of stock $i$ in excess of the risk-free rate in year $t, \ln T V_{t}$ stands for the log of the aggregate trading volume on the German stock market in year $t$; $H Q_{i}$ in Berlin is the dummy for location of company's headquarters in the German capital; $\rho_{i t}^{1}$ denotes stock $i$ daily return serial correlation estimated for year $t$; Bank Crisis $s_{t}$ is Reinhard and Rogoff (2010) bank crisis dummy and GDP p.c. growth ${ }_{t}$ denotes real GDP per capita growth in Germany in year $t$. White period standard

\footnotetext{
${ }^{13}$ We exclude Bochumer Bergwerk henceforth from the analysis, as it has unusually high transaction costs due to several months long periods of non-trading.
} 
errors are reported in parenthesis. Values marked with $* * *, * *$ and $*$ are significant at $1 \%, 5 \%$ and $10 \%$ level respectively. $R^{2}$ is calculated as one minus the fraction of the residual variance to the variance of the dependent variable.

Our results reported in Table 3 largely support recent findings for modern markets. Size has the predicted negative effect on illiquidity and is significant at the $1 \%$ level in all specifications, supporting the finding of Gehrig and Fohlin (2006). The negative and significant (at least at the 10\% level) coefficient for the previous year excess return is in line with findings of Griffin et al. (2004) and Bekaert et al. (2007), as well as Amihud (2002).

The impact of proximity is liquidity enhancing for all specifications and statistically significant at the $5 \%$ level. Stocks of companies with headquarters in the German capital have on average 14 basis points lower transaction costs than stocks of companies incorporated outside of Berlin.

The log of the aggregate trading volume of all German securities as an indicator of the overall trading activity in the market lacks statistical significance in any specification.

On the contrary, the effect of crises, both banking and aggregate, is significant at least at the $10 \%$ level, while dropping time random effects increases statistical significance of crises, so that both become significant at the 1\% level (Table 3 columns 4-5). In the years of banking crises, transaction costs are higher by $42-43$ basis points. Similarly, a one percentage point GDP per capita decline yields an increase in transaction costs by about 2.3-2.7 basis points in the following year. As the maximum fall of the per capita GDP was 1.5 percentage points (in 1899), banking crises seem to have greater economic significance for stock market liquidity.

Hence, stock market liquidity deteriorates during real economy and banking downturns, as investors sell stocks to compensate for labor income shortages or lost banking deposits. ${ }^{14}$ The larger effect of banking crises could be explained by a larger proportion of potentially lost deposits to annual consumption.

Thus we find most of the stylized facts on liquidity in our data, in particular liquidity surges in crises.

\section{Liquidity premiums}

Having established in previous sections that the liquidity in our sample is comparable in level and behavior to modern time periods, we turn to the analysis of the liquidity level and

\footnotetext{
${ }^{14}$ Naes et al. (2011) show that liquidity also dries out before recessions. Even though we find some supportive evidence of it in our data, anticipative liquidity surges are less pronounced than reactive drops in liquidity. For our hypothesis on the impact of cycle length on liquidity risk premium to hold we need only some form of strong cyclicality of liquidity.
} 
liquidity risk premiums. In this section we show that the liquidity risk premium was significant and higher than on modern developed markets. This we attribute to a higher frequency of crises in our sample.

We focus on the covariance of stock illiquidity with market returns as the main channel of liquidity risk. Even though the seminal paper of Acharya and Pedersen (2005), which established the liquidity-adjusted CAPM, also considers covariance of individual stock liquidity with market liquidity and the covariance of individual stock returns with market liquidity, a plethora of empirical studies show that the first channel is by far most pronounced in asset pricing (Acharya and Pedersen 2005, Lee 2011, Hagströmer et al. 2013). Moreover, this risk channel reflects the inability to sell stocks (at reasonable transaction costs) in times of stock market downturns, which is closer to our stylized model and more in line with other theoretical models (e.g. Lynch and Tan 2011), resembling the "risk of joint liquidation" in Wagner (2011).

We proceed in two steps. First, we obtain estimates of liquidity level and liquidity risk premiums using the standard cross-sectional Fama-MacBeth (1973) procedure and compare them to findings on liquidity premiums in modern data. Second, to stress the link to business cycles, we analyze the dynamics of liquidity (level and risk) premiums using a conditional liquidity-adjusted CAPM specification.

\subsection{Cross-sectional analysis of an unconditional LCAPM}

In order to get more adequate estimates of the liquidity level and liquidity risk premiums we run Fama-MacBeth (1973) regressions with Shanken (1992) corrections using individual stocks. ${ }^{15}$ We test the traditional CAPM and several multifactor extensions, including transaction costs and liquidity risk, controlling also for size and momentum factors, as well as for serial daily return autocorrelation. ${ }^{16}$

Transaction costs are our LOT estimates, which are, as the first-order autocorrelation coefficient of daily price percentage changes, calculated over the previous year. Market,

\footnotetext{
${ }^{15}$ Using individual stocks instead of portfolios allows for larger cross-sectional variation of betas, see the discussion in Ang et al. (2010). This approach is gaining popularity in recent literature, e.g. Hou et al. (2011)

${ }^{16} \mathrm{We}$ are aware of possible within firm and within month error clustering, as outlined in Petersen (2009). Having a considerably greater time dimension than cross-section dimension makes the within month clustering the primary problem. However, as Petersen (2009) shows, Fama-MacBeth (1973) technique is able to address it adequately. Turning to within firm clustering, it could be a problem in our data at a first glance, as our right hand side variables are very persistent, since transaction costs change only yearly and betas and autocorrelation coefficient stay constant throughout the sample. But our dependent variable - return - is not persistent at all, thus yielding slightly negatively correlated residuals and thus nullifying the problem of underestimation of standard errors.
} 
small-minus-big (SMB), and Momentum betas are constant for each company throughout the sample. We also include a constant as we do not demean the explanatory variables. 
Table 10. Results of cross-sectional asset pricing regressions

\begin{tabular}{|c|c|c|c|c|c|c|}
\hline & (1) & (2) & (3) & (4) & $\overline{~(5)}$ & (6) \\
\hline \multirow[t]{2}{*}{ Constant } & $0.0044^{* * *}$ & 0.0005 & -0.0021 & -0.0019 & -0.0020 & -0.0024 \\
\hline & 0.0014 & 0.0017 & 0.0021 & 0.0021 & 0.0021 & 0.0023 \\
\hline \multirow{2}{*}{ Market beta $\bar{\lambda}_{\beta}$} & -0.0002 & 0.0020 & $0.0043^{*}$ & $0.0046^{* *}$ & $0.0043^{*}$ & $0.0046^{*}$ \\
\hline & 0.0020 & 0.0020 & 0.0023 & 0.0023 & 0.0023 & 0.0024 \\
\hline Transaction cost & & $0.2867^{* *}$ & 0.1750 & 0.1359 & 0.1591 & 0.1888 \\
\hline lagged $\bar{\lambda}_{T C}^{\prime}$ & & 0.1244 & 0.1276 & 0.1397 & 0.1381 & 0.1540 \\
\hline SMB beta & & & & & $\begin{array}{r}-0.0011 \\
0.0021\end{array}$ & $\begin{array}{r}-0.0019 \\
0.0023\end{array}$ \\
\hline Momentum beta & & & & & & $\begin{array}{r}-0.0011 \\
0.0016\end{array}$ \\
\hline Autocorrelation & & & & -0.0018 & & \\
\hline lagged $\bar{\lambda}_{\rho}$ & & & & 0.0046 & & \\
\hline $\begin{array}{l}\text { Illiquidity risk } \\
\text { premium } \bar{\lambda}_{I}\end{array}$ & & & $\begin{array}{c}-0.2107^{* * *} \\
0.0669\end{array}$ & $\begin{array}{c}-0.2117^{* * *} \\
0.0698\end{array}$ & $\begin{array}{c}- \\
0.2261^{* * *} \\
0.0706\end{array}$ & $\begin{array}{c}-0.2420^{* * *} \\
0.0736\end{array}$ \\
\hline Average $\mathrm{R}^{2}$ & 0.07 & 0.13 & 0.18 & 0.23 & 0.24 & 0.30 \\
\hline$\#$ of stocks & 26 & 26 & 26 & 26 & 26 & 26 \\
\hline $\begin{array}{l}\# \text { of cross- } \\
\text { sections } T\end{array}$ & 264 & 252 & 252 & 252 & 252 & 252 \\
\hline
\end{tabular}

Estimates of the Fama-MacBeth (1973) regressions for the sample period from 1892 to 1913 for 26 companies. Reported coefficient values $\bar{\lambda}_{k}$ are averages of 264 (252 for columns (2)-(6)) regression estimates of the type: $Z_{i t}=\alpha_{t}+\lambda_{t}^{\prime} B_{i t}+u_{i}$, where $\lambda_{t}^{\prime}$ denotes the transposed vector of risk premia and $B_{i t}$ denotes the vector of risk factor loadings, which serve as explanatory variables in each cross section. Standard errors are calculated as $\sqrt{\operatorname{var}\left[\lambda_{k t}\right] \cdot\left(1+\mu^{\prime} \Omega^{-1} \mu\right) / T}$, according to the Fama-MacBeth (1973) procedure with the Shanken (1992) correction, and are reported in 
parentheses. Values marked with $* * *, * *$ and $*$ are significant at the $1 \%, 5 \%$ and $10 \%$ level respectively. Average $R^{2}$ is an arithmetic mean of $R^{2}$ for each cross-section. 
Our results reveal that the CAPM does not hold since the market risk premium is insignificant in all specifications not including liquidity risk (Table 10, columns 1-2). This is in line with empirical results on modern data starting from Fama and French (1992). However, if we account for liquidity risk (columns 3-6) the market risk premium becomes marginally significant (at least at the $10 \%$ level). ${ }^{17}$ In economic terms, a one standard deviation $(0.30)$ increase in sensitivity to market risk boosts expected returns by 14 basis points on a monthly basis or 1.7 percent annualized (given the most general specification, column 7).

The premium for transaction costs is positive; however it is significant at the $5 \%$ level only if we do not include liquidity risk (see Table 10, column 2). A one percentage point higher transaction cost (which is equivalent to moving from the most liquid stocks to the bottom of our sample, see Appendix 1) raises expected monthly return by 14 to 29 basis points or 1.7 percent to 3.5 percent annually, depending on the specification. This range just covers the 3.5 percent annual premium obtained by Acharya and Pedersen (2005) for the US value-weighted portfolios in 1964-1999. The illiquidity premium estimates also suggest an average holding period of three and a half to seven months, which is required for returns net of transaction costs to become equal across different stocks.

We find size insignificant both as characteristic and factor (columns 4 and 6-7 correspondingly), which supports the result of Lee (2011) for modern stocks except emerging markets. Seemingly, size to a large extent proxies liquidity, which is much better captured here by transaction costs. However, the inclusion of the size variable increases, due to correlation with transaction costs, the standard error of the latter coefficient.

Opposite to the findings of Asness et al. (2013), there is no evidence of momentum being priced as a factor: including momentum into the model specification (column 7) yields an insignificant coefficient and does not alter the overall results qualitatively.

The illiquidity risk premium is, as we hypothesized, negative and very strong (columns 3-7). This is due to the undesired negative sensitivity of illiquidity to market movements. Negative market shocks increase illiquidity and vice versa. Thus, the expected return is higher for those stocks for which liquidity deteriorates during market downturns. Our result for the premium on the individual illiquidity sensitivity to market returns is statistically highly significant, in line with results obtained by Lee (2011) for a large battery of stocks from 54 countries and the 1988-2007 sample period (Lee 2011, Tables 3-4), whereas Acharya and Pedersen (2005) for modern US data fails to find a statistically significant premium for this liquidity risk channel alone. The economic extent of the liquidity risk effect in our data surpasses the ones reported

\footnotetext{
${ }^{17}$ This deviates slightly from the findings of Gernandt et al. (2011) for the contemporary (1901-1919) Swedish stock market, who find the market premium still insignificant after accounting for the liquidity risk.
} 
in the literature. If sensitivity to liquidity risk intensifies by one standard deviation (e.g. moves from 0 to -0.00823 ), the expected return increases by 20 basis points per month. Thus, the effect is also economically stronger than for market risk. The difference between maximum and minimum liquidity risk sensitivity is about four times as large and would lead to a 75 basis points increase (see Appendix 7). Annualizing the full range move in liquidity sensitivity would yield a 9.0 percent return increase, which by far exceeds the overall liquidity risk effects of 1.1 percent, reported by Acharya and Pedersen (2005: 398) for the US and 1.5 percent reported by Lee (2011) for the global market, and is still larger than the economic effect of 5.6 percent for modern emerging markets (Lee 2011: 146). ${ }^{18}$ The obtained risk premium is greater than the 7.5\% reported for US market of 1966-1999 and for another risk channel (covariance of individual stock returns with the average market illiquidity) in Pastor and Stambaugh (2003).

The liquidity risk premium on the Berlin Stock Exchange in 1892-1913 can be compared to the one Hagströmer et al. (2013) find for the US stock market in times of Great depression (about 8-10 percent annualized), but exceeds by far their findings for the same market in 1940-2010.

That is, liquidity risk is priced higher than on volatile and quite illiquid modern emerging markets.

\footnotetext{
${ }^{18}$ However, one should take into account that Acharya and Pedersen (2005) use a transformation of Amihud ratio as illiquidity measure, whereby Lee (2011) uses the proportion of zero returns. Moreover, Lee (2011) shrinks somewhat the distribution of betas, taking portfolio betas of 10 pre-ranked portfolios.
} 


\subsection{Analysis of time-variability of liquidity risk premium: conditional LCAPM}

To stress the importance of real economic fragility for the liquidity risk premium we perform a dynamic study. First, we estimate a time-series of realized liquidity risk premiums, which we define as the product of the liquidity risk premium and the covariance of illiquidity and returns in a certain period. Second, we show the link from shocks in real output and banking sector to the size of the realized liquidity risk premium.

For the first step, we analyze the time series dynamics of returns and illiquidity at monthly frequency, applying the multivariate GARCH approach. We follow the general setup of Gibson and Mougeot (2004) and include the conditional covariance of returns and illiquidity as explanatory variable for returns, which allows simultaneously estimating time-varying risk exposure (covariance) and its premium (the latter - time invariable coefficient in the mean equation for returns). As in Gibson and Mougeot (2004), we focus on market index excess returns and average market illiquidity. A significant liquidity risk premium would then be interpreted as a higher expected market excess return in periods when liquidity risk is deemed higher.

We model both series as a VAR(2) process, whereby, besides the conditional covariance, we include the market risk, namely the conditional variance of the market excess returns, into the mean equation for returns:

$$
\begin{aligned}
& r_{t}=a_{01}+a_{111} r_{t-1}+a_{112} r_{t-2}+a_{121} I L_{t-1}+a_{122} I L_{t-2}+\lambda_{1} \operatorname{VarRet}_{t}+\lambda_{2} \operatorname{CovRetIl}_{t}+\varepsilon_{1, t} \\
& I L_{t}=a_{02}+a_{211} r_{t-1}+a_{212} r_{t-2}+a_{221} I L_{t-1}+a_{222} I L_{t-2}+\varepsilon_{2, t} \\
& \varepsilon_{t}=\left[\begin{array}{l}
\varepsilon_{1, t} \\
\varepsilon_{2, t}
\end{array}\right] \\
& \Sigma_{t}=\operatorname{var}\left[\varepsilon_{t} \mid F_{t-1}\right]=\left[\begin{array}{cc}
\operatorname{VarRet}_{t} & \text { CovRetIl }_{t} \\
\text { CovRetIl }_{t} & \operatorname{VarIl}_{t}
\end{array} \mid F_{t-1}\right]
\end{aligned}
$$

Market illiquidity $I L_{t}$ is calculated as the market average transaction cost for the month $t$ : First, we estimate LOT measures at monthly frequency for each stock and, then, average them for each month across our sample of stocks. ${ }^{19}$ As one can see from Table 11, monthly index return is far more volatile than the illiquidity level. The two variables are practically contemporaneously uncorrelated.

\footnotetext{
${ }^{19}$ Monthly LOT estimates for stocks could be noisier than annual. In fact, for 71 months (out of 7128 stockmonths, less than $1 \%$ of the sample) the procedure does not converge. In 16 cases it was due to less than $20 \%$ (about 5 days) of non-zero returns per month. For these months we insert a value of 0.3 , which corresponds to the cap chosen in Acharya and Pedersen (2005), so only 55 out of 7128 stock-month observations are missing. We believe that averaging across stocks allows minimizing noise to an extent similar to taking annual LOT measures instead of monthly in the previous section.
} 
Table 11

\begin{tabular}{llll}
\hline \hline & Mean & Std. dev. & Corr (R, IL) \\
\hline Market Return & 0.0031 & 0.0210 & \\
Average Illiquidity & 0.0089 & 0.0042 & 0.0043 \\
\hline \hline
\end{tabular}

In contrast to Gibson and Mougeot (2004) we use levels of illiquidity and include VAR(2) terms, since our measure of illiquidity is stationary, but persistent, and we need to account for dynamic interdependencies between illiquidity and returns emphasized in Amihud (2002). We model the conditional variance-covariance matrix of shocks $\Sigma_{\mathrm{t}}$ using both Diagonal VEC model and Dynamic Conditional Correlation model of Engle (2002, DCC). We obtain the starting values from the two-step estimator. ${ }^{20}$

The results are displayed in Table 12. Market index excess returns on the monthly frequency do not exhibit first-order autocorrelation and linear dependence on past illiquidity levels. Corresponding coefficients are insignificant. Interestingly, both DVEC and DCC specifications yield a significantly negative second-order autoregression coefficient, which is, however, in economic terms, moderate: a one standard deviation higher return decreases the expected return in two months by 37-39 basis points (according to DCC and DVEC correspondingly). The conditional market risk premium $\lambda_{1}$, the coefficient for the conditional market return variance, is insignificant in both specifications. Thus, the strongest predictor of excess returns is the conditional liquidity risk: the coefficient of the conditional covariance of return and illiquidity coefficient is significant at least at the 5\% level and economically large: a one standard deviation stronger conditional covariance with illiquidity results in a 55-58 basis points (according to DVEC and DCC correspondingly) higher return.

The illiquidity level is very persistent: the sum of the autoregressive coefficients for the LOT measures is 0.7 . Moreover, the adverse effect of past returns on illiquidity is also documented in our data: a one standard deviation of excess market returns leads to a 7 basis points decrease in transaction costs in the following month.

The variance equation coefficients are in line with stylized facts: monthly returns' conditional volatility is quite persistent, $\mathrm{ARCH}$ and $\mathrm{GARCH}$ coefficients sum up to 0.9 in both specifications. Conditional volatility of illiquidity is somewhat less persistent, with the sum of corresponding coefficients of 0.77 . A very high persistence is revealed for the covariance between illiquidity and returns. The long memory coefficient amounts to 0.95 in the DVEC

\footnotetext{
${ }^{20}$ Starting values are available on demand.
} 
specification. The long memory of the dynamic conditional correlation coefficient, has a value of 0.98 .

Table 12. Conditional risk-premia model

\begin{tabular}{|c|c|c|c|c|}
\hline \multirow[t]{2}{*}{ Parameter } & \multicolumn{2}{|c|}{ VAR(2)-DVEC } & \multicolumn{2}{|c|}{ VAR(2)-DCC } \\
\hline & Return & Illiquidity & Return & Illiquidity \\
\hline \multirow[t]{2}{*}{ intercept } & 0.0059 & $0.0026 * * *$ & 0.0057 & $0.0025 * * *$ \\
\hline & $(0.0067)$ & $(0.0005)$ & $(0.0061)$ & $(0.0005)$ \\
\hline \multirow{2}{*}{ Return $_{\mathrm{t}-1}$} & 0.0971 & $-0.0324 * * *$ & 0.1034 & $-0.0339 * * *$ \\
\hline & $(0.0768)$ & $(0.0091)$ & $(0.0725)$ & $(0.0088)$ \\
\hline \multirow[t]{2}{*}{ Return $_{t-2}$} & $-0.1852 * *$ & -0.0058 & $-0.1741 * *$ & -0.0057 \\
\hline & $(0.0736)$ & $(0.0119)$ & $(0.0780)$ & $(0.0123)$ \\
\hline \multirow{2}{*}{ Illiquidity $_{\mathrm{t}-1}$} & 0.1980 & $0.4694 * * *$ & 0.1823 & $0.4824 * * *$ \\
\hline & $(0.5348)$ & $(0.0865)$ & $(0.5308)$ & $(0.0787)$ \\
\hline \multirow[t]{2}{*}{ Illiquidity $_{\mathrm{t}-2}$} & -0.3090 & $0.2339 * *$ & -0.3526 & $0.2379 * * *$ \\
\hline & $(0.4588)$ & $(0.0918)$ & $(0.5010)$ & $(0.0840)$ \\
\hline \multirow{2}{*}{$\operatorname{VarRet}_{\mathrm{t}}$} & -9.3627 & & -15.9170 & \\
\hline & $(17.3467)$ & & $(17.3771)$ & \\
\hline \multirow[t]{2}{*}{ CovRetIl $_{t}$} & $-1012.6480 * *$ & & $-625.3497 * *$ & \\
\hline & $(478.7244)$ & & $(318.4984)$ & \\
\hline \multirow[t]{2}{*}{ const } & $4.00 \times 10^{-5}$ & $2.00 \times 10^{-6^{* * *}}$ & $3.80 \times 10^{-5}$ & $2.00 \times 10^{-6^{* * * *}}$ \\
\hline & $\left(3.40 \times 10^{-5}\right)$ & $\left(1.00 \times 10^{-6}\right)$ & $\left(3.30 \times 10^{-5}\right)$ & $\left(1.00 \times 10^{-6}\right)$ \\
\hline \multirow[t]{2}{*}{$\mathrm{ARCH}$} & $0.0797 *$ & $0.1317 * *$ & $0.0712 *$ & $0.1048 * *$ \\
\hline & $(0.0447)$ & $(0.0602)$ & $(0.0399)$ & $(0.0508)$ \\
\hline \multirow{2}{*}{ GARCH } & $0.8236^{* * *}$ & $0.6322 * * *$ & $0.8396^{* * *}$ & $0.6628 * * *$ \\
\hline & $(0.1112)$ & $(0.1118)$ & $(0.1016)$ & $(0.1193)$ \\
\hline \multirow[t]{2}{*}{ Const cov } & \multicolumn{2}{|c|}{0.0000} & & \\
\hline & \multicolumn{2}{|c|}{$(0.0000)$} & & \\
\hline $\mathrm{ARCH} \operatorname{cov} /$ & \multicolumn{2}{|c|}{0.0112} & \multicolumn{2}{|c|}{$0.0178 * *$} \\
\hline DCC alpha & \multicolumn{2}{|c|}{$(0.0089)$} & \multicolumn{2}{|c|}{$(0.0089)$} \\
\hline GARCH cov / & \multicolumn{2}{|c|}{$0.9522 * * *$} & \multicolumn{2}{|c|}{$0.9816^{* * *}$} \\
\hline DCC beta & \multicolumn{2}{|c|}{$(0.0232)$} & \multicolumn{2}{|c|}{$(0.0118)$} \\
\hline LB 10 & 6.37 & 7.17 & 6.03 & 6.85 \\
\hline (p-value) & $(0.78)$ & $(0.71)$ & $(0.81)$ & $(0.74)$ \\
\hline McLeod-Li 10 & 10.44 & 3.60 & 10.02 & 4.72 \\
\hline (p-value) & $(0.40)$ & $(0.96)$ & $(0.44)$ & $(0.91)$ \\
\hline Multivariate & \multicolumn{2}{|c|}{22.25} & \multicolumn{2}{|c|}{19.82} \\
\hline Q 10 (p-value) & \multicolumn{2}{|c|}{ (0.99) } & \multicolumn{2}{|c|}{$(1.00)$} \\
\hline Log & & & & 3711 \\
\hline Likelihood & & .0547 & & \\
\hline Obs & & 62 & & 62 \\
\hline
\end{tabular}

Estimates of equation parameters of VAR(2)-MGARCH-in-mean models (DVEC, DCC) for market monthly excess returns and aggregate market illiquidity described in Eq. 11-12 for the sample period from 1892 to 1913 . Aggregate market illiquidity is calculated as the average LOT measure of all stocks included into the index. Values marked with $* * *, * *$ and $*$ are significant at the $1 \%, 5 \%$ and $10 \%$ level, respectively.

To emphasize and illustrate our key results, we plot the realized liquidity risk premium , in a graph showing also the banking crises as shaded areas (Figure 2). 
Figure 2. Realized liquidity risk premium

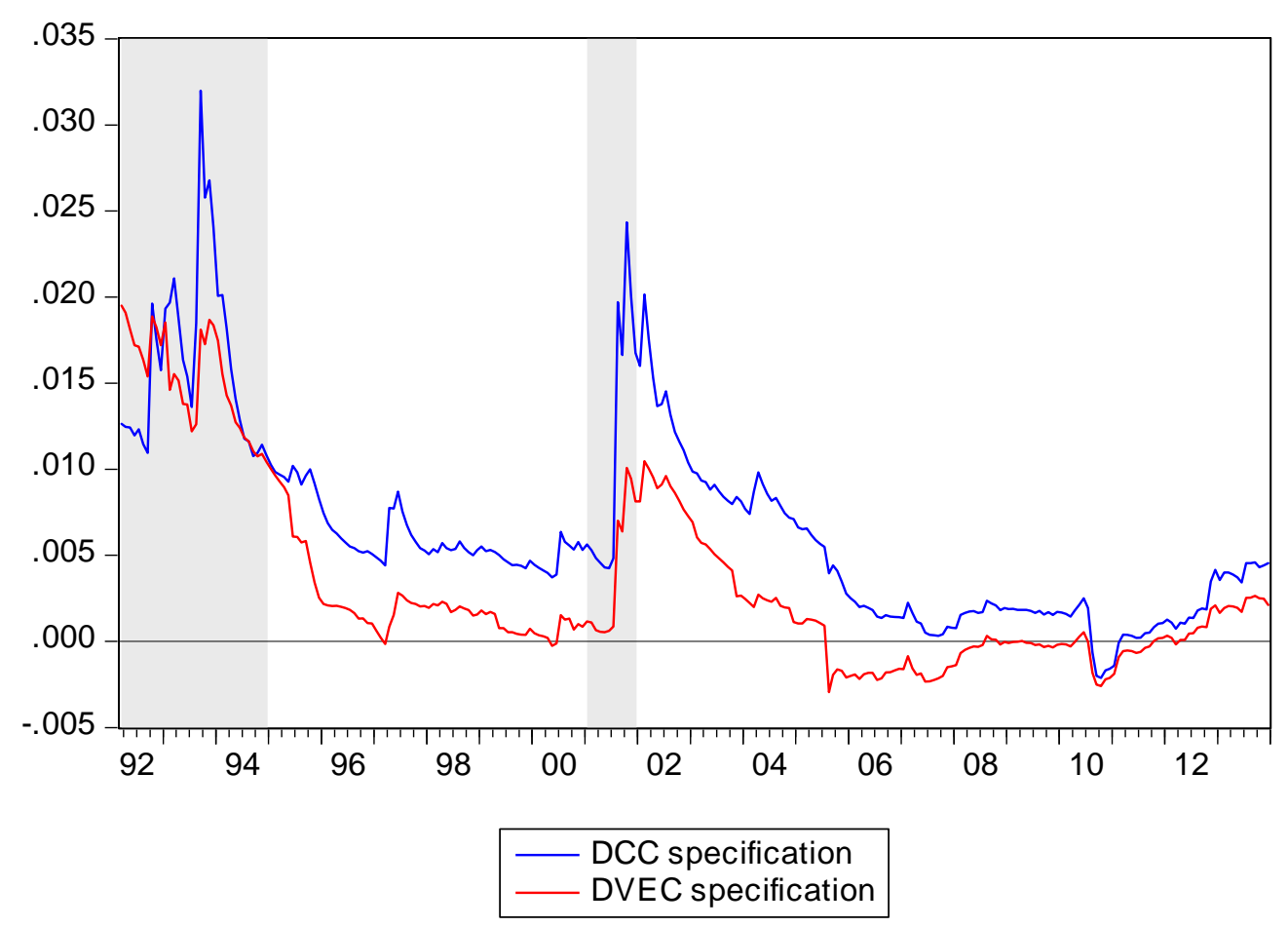

It can be seen from figure 2 that liquidity-risk-caused expected excess return increases after banking crises (or during an ongoing banking crisis). Moreover, negative shocks to the real economy may affect liquidity risk. This relationship between liquidity risk premium on the one hand and banking crises and negative growth on the other hand can be empirically estimated via a distributed lag regression of the realized liquidity risk premium (denoted $L R P$ ) on GDP per capita growth and banking crises:

$$
\begin{aligned}
& L R P_{t}=\underset{(0.0126)}{0.0718}-\underset{(0.2184)}{0.3009 \cdot \Delta \% G D P p . c_{\cdot_{t-1}}}-\underset{(0.3362)}{1.0756} \cdot \Delta \% G D P p . c_{t_{t-2}}+\underset{(0.0185)}{0.1205 \cdot B C_{t-1}}+\varepsilon_{t} \\
& R^{2}=74.0 \% \quad L B_{1}=3.71 L B_{3}=7.56,
\end{aligned}
$$

where the Newey-West autocorrelation-adjusted standard errors are in parentheses. Two lags of GDP growth and lags of the banking crisis dummy explain $74 \%$ of the risk premium variation. Residual autocorrelation is significant at the $10 \%$ but not at the $5 \%$ level at reasonable lags. The second lag of GDP growth is significant at the $5 \%$ level, and the lagged banking crises coefficient at the $1 \%$ level.

The effect of bank crises periods is economically stronger than the effect of the real economy shocks: the former explains about $64 \%$ of the realized liquidity risk premium variation, whereas the latter only $10 \%$. A possible explanation would be a higher magnitude of losses during banking crises: Whereas real income declines are in lower single digits percentage 
points, one would expect higher losses resulting from bank failures proportionally to an annual GDP per capita.

The main results of this section are independent of the specification of the variance covariance matrix: The significance and the magnitude of coefficients are even stronger when using the DVEC specification. ${ }^{21}$

Thus, the dynamic model shows that the realized liquidity risk premium is driven by previous shocks to real economy and the banking sector, and hence supports our hypothesis of the moderating impact of business cycle length on the liquidity risk premium.

\section{Robustness checks}

To show that our results are not driven by the choice of (a) market index and (b) illiquidity measure, we re-run estimations for alternatives.

First, since the Gelman Burhop (2008) market index is a value-weighted one, we check robustness of the unconditional asset pricing relationships using equally weighted returns of the 27 index constituents. The qualitative result remains: the liquidity risk premium is statistically significant (at least on the 5\% level), and generates 79 bps expected return monthly or 9.5\% annualized (see Appendix 8, Table A8.1). Thus, using equally-weighted market returns even widens the economic impact of liquidity risk.

We also allow altering the composition of the market index, taking the Eube (1998) index instead, which is a much wider stock market index for the Berlin stock exchange, but which is calculated at monthly frequency. ${ }^{22}$ The results stay the same (see Appendix 8, Table A8.2): liquidity risk is highly statistically significant; the economic impact is still huge: The full range move in sensitivity to illiquidity risk generates $61 \mathrm{bps}$ monthly expected return or $7.4 \%$ annualized, surpassing the premium for modern emerging markets reported by Lee (2011).

To address concerns that the LOT measure can be distorted due to idiosyncratic shocks, we run the analysis for the proportion of zero returns as another measure for illiquidity. Proportion of zero returns is believed to be substantially less affected by idiosyncratic volatility. If there is any impact, then smaller volatility would lead due to price discreteness to a higher zero return proportion and hence higher illiquidity measure (Campbell et al. 1997, p. 110ff.), whereas the distortion for LOT is believed to go in the opposite direction (see Borisenko and Gelman 2014).

\footnotetext{
${ }^{21}$ See Appendix 7.

${ }^{22}$ Thus, we cannot apply it to recalculate LOT measures (which require daily observations), but to obtain alternative measures of the market and liquidity risk (market and liquidity risk betas). Eube (1998) has also some methodological shortcomings, primarily concerning its short-run accuracy, as discussed in Gelman and Burhop (2008), but they can be neglected at this point, as we are measuring long-run effects.
} 
Changing the illiquidity proxy to zero returns ratio somewhat weakens the results with respect to the illiquidity risk premium (see Appendix 9). Statistical significance of the liquidity risk premium is lower when using the proportion of zero returns as a measure: the liquidity risk premium is significant at the 5\% level for the liquidity-adjusted CAPM (column 3) and at the $10 \%$ level for the model augmented with serial correlation, SMB and Momentum factors (columns 4-6). Thereby in all specifications where the liquidity risk is present (columns 3-6) it is the only factor that statistically matters for asset pricing. Also, economically it is still stronger than modern estimates for developed markets: a one standard deviation in illiquidity beta raises expected excess return by 9 basis points per month, or 1.1\% per year. A full move from the least responsive to the most inversely affected stocks results into a 32 basis points increase per month or 3.9\% annualized. Even though the use of this alternative proxy reduces the economic effect by a half, it is still three times the premium obtained for the US in Acharya and Pedersen (2005), and more than double the effect for the global market obtained by Lee (2011).

The findings for the dynamics of the liquidity risk premium using the proportion of zero return days are fully supportive of our original results. The premium for the conditional liquidity risk is highly significant, whereas market risk is not significant at any conventional level (see table A10.1). Two lags of real economic growth and the a one year lagged banking crises dummy explain above $84 \%$ of the realized premium variation (in DCC specification, $R^{2}$ is $82 \%$ in DVEC specification; see Appendix 10), thereby real growth has an adverse impact and accounts for $8 \%$, and banking crisis has a magnifying impact and explains the rest. Thus, our finding that the liquidity risk premium was considerably higher due to the shorter business cycle survives all robustness checks. 


\section{Conclusion}

We find that in spite of low transaction costs and of low return volatility the Berlin Stock Exchange around 1900 provided for a higher liquidity risk premium than the modern developed markets. We link this phenomenon to the shorter business cycles in the Pre-WWI period compared to the "Great Moderation" a century later. Likely because of the more frequent occurrence of real economic downturns, accompanied by banking crises, investors valued the opportunity of cheaper liquidation of stock market assets much higher than on a present day developed stock market. We provide support of this causal relationship by showing with help of a conditional model that most of the liquidity risk caused excess returns are realized after banking crises and real GDP per capita declines. Hence, this allows pinning down the business cycle length (and not the stock market volatility or illiquidity level) as the main driver of variation in liquidity risk premium. This could also explain the modern differences in premium between developed and emerging markets. 


\section{References}

Acharya, V. V., and Pedersen, L.H. (2005)

Asset pricing with liquidity risk

Journal of Financial Economics, 77, 375-410

Amihud, Y (2002)

Illiquidity and stock returns: cross-section and time-series effects

Journal of Financial Markets, 5, 31-56

Amihud, Y. and H. Mendelson (1986)

Asset pricing and the bid-ask spread

Journal of Financial Economics, 17, 223-249

Amihud, Y., H. Mendelson, and B. Lauterbach (1997)

Market microstructure and securities values: Evidence from the Tel Aviv Stock

Exchange

Journal of Financial Economics, 45 (3), 365-390

Ang, A. Liu, J., and Schwarz, K. (2010)

Using Stocks or Portfolios in Tests of Factor Models

Working paper, Columbia University

Arellano, M. and O. Bover (1995):

Another Look at the Instrumental-Variable Estimation of Error-Components Models Journal of Econometrics, 68, 29-51

Asness, C., Moskowitz, T., and Pedersen, L. H. (2013)

Value and momentum everywhere

Journal of Finance, 68, 929-986

Asparouhova, E., Bessembinder, H., and Kalcheva, I. (2009)

Liquidity biases in asset pricing tests

Journal of Financial Economics, 96, 215-237

Baltagi, B.H., Li, D., and Li, Q. (2006)

Transaction tax and stock market behaviour: Evidence from an emerging market Empirical Economics, 31, 393-408

Baltzer, M. (2006)

Cross-listed stocks as an information vehicle of speculation: Evidence from

European cross-listings in the early 1870 s

European Review of Economic History, 10, 301-327

Barclay, M., Hendershott, T., and. Jones, C. (2008)

Order Consolidation, Price Efficiency, and Extreme Liquidity Shocks

Journal of Financial and Quantitative Analysis, 43, 93-122

Barlevy, G., and Veronesi, P. (2000)

Information Acquisition in Financial Markets

Review of Economic Studies, 67, 79-90

Baruch, S. (2005)

Who Benefits from an Open Limit Order Book?

Journal of Business, 78,. 1267-1306

Beber, A., Driessen, J. and Tuijp, P. (2012)

Pricing Liquidity Risk with Heterogeneous Investment Horizons

Working paper, WFA 2012 conference

Bekaert, G., Harvey, C., and Lundblad, C. (2007)

Liquidity and Expected Returns: Lessons from Emerging Markets

Review of Financial Studies, 20, 1783-831.

Bernhardt, D., Hollifield, B., and Hughson, E. (1995)

Investment and Insider Trading

Review of Financial Studies, 8, 501-543 
Bloomfield, R. and O'Hara, M. (1999)

Market transparency: who wins and who loses?

Review of Financial Studies, 12, 5-35

Buss, A., Uppal, R., and Vilkov, G. (2014)

Asset Prices in General Equilibrium with Recursive Utility and Illiquidity Induced by Transactions Costs

INSEAD Working paper series, 2014/01/FIN

Buss, A., and Dumas (2013)

Financial-Market Equilibrium With Friction

NBER Working Paper Series, Working Paper 19155

Brennan, M., and A. Subrahmanyam (1996).

Market microstructure and asset pricing: On the compensation for illiquidity in stock returns.

Journal of Financial Economics, 41, 441-64.

Campbell, J.W., Lo, A.W., and MacKinlay, A.C. (1997)

The Econometrics of Financial Markets

University of California Press

Chalmers, J.M.R. and Kadlec, G.B. (1998)

An empirical examination of the amortized spread

Journal of Financial Economics, 48, 159-198

Chang, R.P., S.G. Rhee, G.R. Stone, and N. Tang (2008)

How does the call market method affect price efficiency? Evidence from the

Singapore stock market

Journal of Banking and Finance, 32 (10), 2205-2219

Chelley-Steeley, P.L. (2008)

Market quality changes in the London stock market

Journal of Banking and Finance, 32 (10), 2248-2253

Chordia, T., Huh, S.-W., and A. Subrahmanyam (2009)

Theory-based illiquidity and asset pricing

Review of Financial Studies, 22, 3629-3668

Chordia, T., Roll, R. and A. Subrahmanyam (2002)

Order imbalance, liquidity and market returns

Journal of Financial Economics, 65, 111-130

Dow, J. (2004)

Is Liquidity Self Fulfilling?

Journal of Business, 77, 895-908

Eleswarapu, V.R. (1997)

Cost of transacting and expected returns in the NASDAQ market

Journal of Finance, 52, 2113-2127

Eleswarapu, V., and M. Reinganum (1993)

The seasonal behaviour of the liquidity premium in asset pricing.

Journal of Financial Economics, 34, 373-86.

Fama E.F., J. MacBeth (1973)

Risk, return, and equilibrium: Empirical tests

Journal of Political Economy, 91, p.607-636

Fohlin, C. (2007)

Finance capitalism and Germany's rise to industrial power

Cambridge University Press, Cambridge

Foucault T., Moinas, S., and Theissen, E. (2007)

Does Anonymity Matter in Electronic Limit Order Markets?

Review of Financial Studies, 20, 1707-1747 
Franks, J., Mayer, C., and Wagner, H.F. (2006)

The origins of the German corporation - Finance, ownership and control

Review of Finance, 10, 537-585

Gehrig, T. and Fohlin, C. (2006)

Trading costs in early securities markets: The case of the Berlin stock exchange 18801910

Review of Finance, 10, 587-612

Gelman, S. and Burhop, C. (2008)

Taxation, regulation, and the information efficiency of the Berlin stock exchange, 1892-1913

European Review of Economic History, 12, 39-66

George, T., Kaul, G., and Nimalendran, M. (1991)

Estimation of the bid ask spread and its components: A new approach

Review of Financial Studies, 4, 623-656

Gernandt, O., Palm, T., and Waldenström, D. (2011)

Liquidity premiums during the industrial break-through: Evidence from the Stockholm Stock Exchange, 1901-1919

Forthcoming in European Review of Economic History

Goldstein, M., Hotchkiss, E. and Sirri, E. (2007)

Transparency and Liquidity: A Controlled Experiment on Corporate Bonds

Review of Financial Studies, 20, 235-273

Goyenko, R., Holden, C., and Trzcinka, C. (2009)

Do liquidity measures measure liquidity?

Journal of Financial Economics, 92, 153-181.

Griffin, J. M., F. Nardari, and R. M. Stulz. (2004)

Are Daily Cross-border Equity Flows Pushed or Pulled?

Review of Economics and Statistics, 86, 641-57.

Hagströmer, B., Hansson, B., and Nilsson, B. (2013)

The components of the illiquidity premium: An empirical analysis of US stocks 19272010

Journal of Banking \& Finance, 37, 4476-4487

Hameed, A., W. Kang, and S. Viswanathan. (2010)

Stock Market Declines and Liquidity

Journal of Finance, 65, 257-293

Hau, H. (2006)

The role of transaction costs for financial volatility: Evidence from the Paris

Bourse

Journal of the European Economic Association, 4, 862-890

Heaton, J., and D. J. Lucas, (1996)

Evaluating the Effects of Incomplete Markets on Risk Sharing and Asset Pricing

Journal of Political Economy, 104, 443-487.

Hou, K (2007)

Industry information diffusion and the lead-lag effect in stock returns

Review of Financial Studies, 20, 1113 - 1138

Hou, K. and Moskowitz, T. (2005)

Market frictions, price delay, and the cross-section of expected returns

Review of Financial Studies, 18, $981-1020$

Huberman, G. (2001)

Familiarity breeds investment.

Review of Financial Studies 14,659-680.

Jacobs, H., and Weber,M. (2012). 
The trading volume impact of local bias: evidence from a natural experiment.

Review of Finance, 14, 867-901

Jensen, M.C. (1978)

Some anomalous evidence regarding market efficiency

Journal of Financial Economics, 6, 95-102

Kalay, A., L. Wei, and A. Wohl (2002)

Continuous trading or call auctions: Revealed preferences of investors at the Tel Aviv

Stock Exchange

Journal of Finance, 57 (1), 523-542

Kyle, A. S. (1985)

Continuous Auctions and Insider Trading

Econometrica, 53, 1315-1335

Lagoarde-Segot, T. (2009)

Financial reforms and time-varying microstructures in emerging equity markets

Journal of Banking and Finance, 33, 1755-1769

Lee, K.-H. (2011)

The world price of liquidity risk

Journal of Financial Economics, 99, 136-161

Lesmond, D. (2005)

Liquidity of Emerging markets

Journal of Financial Economics, 77, 411-452

Lesmond, D., Ogden, J., and Trzcinka, C. (1999)

A new estimate of transaction costs

Review of Financial Studies, 12, 1113-1141

Liefmann, R. (1923)

Beteiligungs- und Finanzierungsgesellschaften

$4^{\text {th }}$ Edition, Fischer, Jena

Llorente, G., Michaely, R., Saar, G., and Wang, J. (2002)

Dynamic Volume-Return Relation of Individual Stocks

Review of Financial Studies, 15, 1005-1047

Loughran, T., and Schultz, P. (2005)

Liquidity: Urban versus rural firms

Journal of Financial Economics, 78, 341-374

Lynch, A., and Tan, S. (2011)

Explaining the Magnitude of Liquidity Premia: The Roles of Return Predictability,

Wealth Shocks, and State-Dependent Transaction Costs

Journal of Finance, 66, 1329-1368

Madhavan, A., Porter, D., and Weaver, D. (2005)

Should securities markets be transparent?

Journal of Financial Markets, 8, 266-288

Næs, R, Skjeltorp, J. and Ødegaard, B. (2011)

Stock Market Liquidity and the Business Cycle.

Journal of Finance 66, 139-176

Obst, G. (1921)

Das Bankgeschäft. Volume 1: Verkehrstechnik und Betriebs-Einrichtungen

$5^{\text {th }}$ Edition, Carl Ernst Poeschel Verlag, Stuttgart

Pagano, M. (1989)

Endogenous market thinness and stock price volatility

Review of Economic Studies, 56, 269-288

Pagano, M. and Röell, A. (1996) 
Transparency and Liquidity: A Comparison of Auction and Dealer Markets with Informed Trading

Journal of Finance, 51, 579-611

Pagano, M. and Schwartz, R. (2003)

A closing call's impact on market quality at Euronext Paris

Journal of Financial Economics 68 (2003), pp. 439-484

Pastor, L. and Stambaugh,R.F. (2003)

Liquidity risk and expected stock returns

Journal of Political Economy, 111, 642-685

Rajan, R.G. and Zingales, L. (2003)

The great reversals: The politics of financial development in the twentieth century

Journal of Financial Economics, 69, 5-50

Reinhart, C., and Rogoff, K. (2010).

Growth in a Time of Debt

American Economic Review, 100(2), 573-78.

Rochet, J.-C., and Vila J.-L. (1994)

Insider Trading without Normality

Review of Economic Studies, 61, 131-152

Roll, R. (1984)

A simple implicit measure of the bid-ask spread in an efficient market

Journal of Finance, 39, 1117-1140

Schnitzlein, C.R. (1996)

Call and continuous trading mechanisms under asymmetric information: An

experimental investigation

Journal of Finance, 51 (2), 613-636

Theissen, E. (2000)

Market structure, informational efficiency and liquidity: An experimental

comparison of auction and dealer markets

Journal of Financial Markets, 3 (4), 333-363

Shanken, J. (1992)

On the Estimation of Beta-Pricing Models

Review of Financial Studies, 5(1), 1-33.

Shive, S. (2012)

Local investors, price discovery, and market efficiency

Journal of Financial Economics, 104, 145-161

Watanabe, A., and Watanabe, M. (2008)

Time-Varying Liquidity Risk and the Cross Section of Stock Returns

Review of Financial Studies, 21, 2449-2486

Weigt, A. (2005)

Der deutsche Kapitalmarkt vor dem Ersten Weltkrieg - Gründerboom, Gründerkrise

und Effizienz des deutschen Aktienmarktes bis 1914

Peter Lang Verlag, Frankfurt am Main

Wetzel, C. (1996)

Die Auswirkungen des Reichsbörsengesetzes von 1896 auf die Effektenbörsen im Deutschen Reich, insbesondere auf die Berliner Fondbörse

Münster, LIT Verlag 1996 
Appendix 1: Average transaction costs of corporations

\begin{tabular}{|c|c|c|}
\hline Number & Name & $\begin{array}{c}\text { Average } \\
\text { LOT } \\
\text { measure }\end{array}$ \\
\hline 1 & AG für Anilinfabrikation & 0.0084 \\
\hline & Allgemeine & 0.0041 \\
\hline 2 & Elektricitätsgesellschaft & \\
\hline & Berlin-Anhaltinische & 0.0081 \\
\hline 3 & Maschinenbau & \\
\hline 4 & $\begin{array}{l}\text { Bochumer Bergwerk (Lit } \\
\text { C) }\end{array}$ & 0.0295 \\
\hline 5 & $\begin{array}{l}\text { Bank für Handel und } \\
\text { Industrie }\end{array}$ & 0.0038 \\
\hline 6 & Deutsche Bank & 0.0022 \\
\hline 7 & Dresdner Bank & 0.0026 \\
\hline 8 & $\begin{array}{l}\text { Deutsche Jute Spinnerei } \\
\text { und Weberei }\end{array}$ & 0.0106 \\
\hline 9 & Deutsche Spiegelglas & 0.0108 \\
\hline 10 & $\begin{array}{l}\text { Erdmannsdorfer Spinnerei } \\
\text { Gelsenkirchener }\end{array}$ & $\begin{array}{l}0.0165 \\
0.0027\end{array}$ \\
\hline 11 & Bergwerksgesellschaft & \\
\hline 12 & $\begin{array}{l}\text { Gerresheimer Glashütten } \\
\text { Hallesche }\end{array}$ & $\begin{array}{l}0.0128 \\
0.0105\end{array}$ \\
\hline 13 & Maschinenfabriken & \\
\hline 14 & $\begin{array}{l}\text { Harpener Bergbau AG } \\
\text { Kattowitzer AG für }\end{array}$ & $\begin{array}{l}0.0028 \\
0.0056\end{array}$ \\
\hline 15 & Bergbau und Eisen & \\
\hline 16 & $\begin{array}{l}\text { Maschinenfabrik Kappel } \\
\text { Norddeutsche }\end{array}$ & $\begin{array}{l}0.0121 \\
0.0114\end{array}$ \\
\hline 17 & Wollkämmerei & \\
\hline 18 & $\begin{array}{l}\text { Oberschlesische Portland- } \\
\text { Cement AG }\end{array}$ & 0.0105 \\
\hline 19 & Rheinische Stahlwerke & 0.0066 \\
\hline 20 & Rositzer Zuckerfabrik & 0.0103 \\
\hline 21 & $\begin{array}{l}\text { Schaaffhausen'scher } \\
\text { Bankverein }\end{array}$ & 0.0048 \\
\hline 22 & $\begin{array}{l}\text { Chemische Fabrik } \\
\text { vormals Schering }\end{array}$ & 0.0096 \\
\hline 23 & Schlesische Zinkhütten & 0.0093 \\
\hline 24 & $\begin{array}{l}\text { Schlesische Leinen- } \\
\text { Industrie }\end{array}$ & 0.0120 \\
\hline 25 & Schultheiss Brauerei & 0.0059 \\
\hline 26 & Siemens Glas-Industrie & 0.0071 \\
\hline 27 & Stettiner Chamottewaren & 0.0078 \\
\hline
\end{tabular}

Source: Gelman and Burhop (2008), own calculations. 


\section{Appendix 2: explanatory variables, used in the paper}

\begin{tabular}{|c|c|c|}
\hline Notation & Variable & Variable construction \\
\hline$M C_{i t} / \sum M C_{i t}$ & $\begin{array}{l}\text { Relative market } \\
\text { capitalization }\end{array}$ & $\begin{array}{l}\text { Share of market capitalization of the company } i \text { in the } \\
\text { total market cap of all } 27 \text { constituents of the Gelman \& } \\
\text { Burhop (2008) index in the year } t\end{array}$ \\
\hline$X R_{i, t}$ & Excess return & $\begin{array}{l}\text { Simple net return of stock } i \text { in year } t \text { minus the risk-free } \\
\text { rate (for the risk-free rate we take the money market } \\
\text { rate, NBER series 13018) }\end{array}$ \\
\hline $\ln T V_{t}$ & $\begin{array}{l}\text { Log trading } \\
\text { volume }\end{array}$ & $\begin{array}{l}\text { Log of the aggregate trading volume in Reichsmark on } \\
\text { the German stock market (on all stock exchanges) in } \\
\text { year } t \text { (see Appendix } 7 \text { ) }\end{array}$ \\
\hline HQ in Berlin & $\begin{array}{l}\text { Location in Berlin } \\
\text { dummy }\end{array}$ & $\begin{array}{l}\text { Dummy variable: } 1 \text { if company's } i \text { headquarters are } \\
\text { located in Berlin, } 0 \text { otherwise }\end{array}$ \\
\hline$\rho_{i, t}^{1}$ & $\begin{array}{l}\text { Daily return } \\
\text { autocorrelation }\end{array}$ & $\begin{array}{l}\text { First-order autocorrelation coefficient for daily returns } \\
\text { of stock } i \text { in year } t\end{array}$ \\
\hline 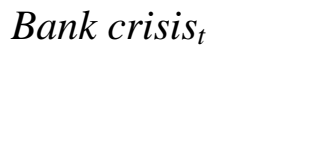 & $\begin{array}{l}\text { Bank crisis } \\
\text { dummy }\end{array}$ & $\begin{array}{l}\text { Dummy variable: } 1 \text { if the year is considered to be a } \\
\text { bank crisis year for Germany in Reinhard and Rogoff } \\
\text { (2010), } 0 \text { otherwise }\end{array}$ \\
\hline GDP p.c. growth & $\begin{array}{l}\text { Real GDP per } \\
\text { capita growth }\end{array}$ & $\begin{array}{l}\text { Growth rate of: real GDP of Germany (taken from } \\
\text { Burhop and Wolff 2005), divided by German } \\
\text { population in corresponding year }\end{array}$ \\
\hline
\end{tabular}


Appendix 3: Constituents of the "small" and "big" portfolios

\begin{tabular}{|c|c|c|c|c|c|c|c|c|}
\hline \multicolumn{9}{|c|}{ "Small" portfolio constituents } \\
\hline \multirow[t]{15}{*}{ Period } & 1892 & 1893-1894 & $1895-1903$ & 1904-1907 & 1908-1910 & 1911 & 1912 & 1913 \\
\hline & \multirow{5}{*}{$\begin{array}{l}\text { Maschinenfabri } \\
\text { k Kappel } \\
\text { Rositzer } \\
\text { Zuckerfabrik }\end{array}$} & \multirow{2}{*}{$\begin{array}{l}\text { Maschinenfabri } \\
\text { k Kappel }\end{array}$} & \multirow{2}{*}{$\begin{array}{l}\text { Maschinenfabri } \\
\text { k Kappel }\end{array}$} & \multirow{2}{*}{$\begin{array}{l}\text { Maschinenfabri } \\
\text { k Kappel }\end{array}$} & \multirow{2}{*}{$\begin{array}{l}\text { Erdmannsdorfer } \\
\text { Spinnerei }\end{array}$} & \multirow{2}{*}{$\begin{array}{l}\text { Erdmannsdorfer } \\
\text { Spinnerei }\end{array}$} & \multirow{2}{*}{$\begin{array}{l}\text { Erdmannsdorfer } \\
\text { Spinnerei }\end{array}$} & \multirow{2}{*}{$\begin{array}{l}\text { Erdmannsdorfer } \\
\text { Spinnerei }\end{array}$} \\
\hline & & & & & & & & \\
\hline & & Oberschlesische & Oberschlesische & Oberschlesische & \multirow{3}{*}{$\begin{array}{l}\text { Maschinenfabri } \\
\text { k Kappel }\end{array}$} & \multirow{3}{*}{$\begin{array}{l}\text { Maschinenfabri } \\
\text { k Kappel }\end{array}$} & \multirow{3}{*}{$\begin{array}{l}\text { Maschinenfabri } \\
\text { k Kappel }\end{array}$} & \multirow{3}{*}{$\begin{array}{l}\text { Maschinenfabri } \\
\text { k Kappel }\end{array}$} \\
\hline & & Portland- & Portland- & Portland- & & & & \\
\hline & & Cement AG & Cement AG & Cement AG & & & & \\
\hline & Oberschlesische & Deutsche & Deutsche & Deutsche Jute & Deutsche Jute & Deutsche Jute & Deutsche Jute & Rositzer \\
\hline & \multirow{2}{*}{$\begin{array}{l}\text { Portland- } \\
\text { Cement AG }\end{array}$} & \multirow[t]{2}{*}{ Spiegelglas } & \multirow[t]{2}{*}{ Spiegelglas } & Spinnerei und & Spinnerei und & Spinnerei und & Spinnerei und & \multirow[t]{2}{*}{ Zuckerfabrik } \\
\hline & & & & Weberei & Weberei & Weberei & Weberei & \\
\hline & Deutsche & Deutsche Jute & Deutsche Jute & Erdmannsdorfer & Oberschlesische & Oberschlesische & Oberschlesische & Oberschlesische \\
\hline & \multirow[t]{2}{*}{ Spiegelglas } & \multirow{2}{*}{$\begin{array}{l}\text { Spinnerei und } \\
\text { Weberei }\end{array}$} & \multirow{2}{*}{$\begin{array}{l}\text { Spinnerei und } \\
\text { Weberei }\end{array}$} & \multirow[t]{2}{*}{ Spinnerei } & Portland- & Portland- & Portland- & \multirow{5}{*}{$\begin{array}{l}\text { Portland- } \\
\text { Cement AG } \\
\text { Hallesche } \\
\text { Maschinenfabri } \\
\text { ken }\end{array}$} \\
\hline & & & & & Cement AG & Cement AG & Cement AG & \\
\hline & Berlin- & Berlin- & Erdmannsdorfer & Hallesche & Rositzer & Hallesche & Rositzer & \\
\hline & Anhaltinische & Anhaltinische & \multirow[t]{2}{*}{ Spinnerei } & Maschinenfabri & \multirow[t]{2}{*}{ Zuckerfabrik } & Maschinenfabri & \multirow{2}{*}{ Zuckerfabrik } & \\
\hline & Maschinenbau & Maschinenbau & & ken & & ken & & \\
\hline \multicolumn{9}{|c|}{ "Big" portfolio constituents } \\
\hline \multirow[t]{13}{*}{ Period } & $1892-1895$ & 1896 & $1897-1905$ & 1906-1908 & 1909-1910 & 1911-1913 & & \\
\hline & Gelsenkirchener & Harpener & Allgemeine & Gelsenkirchener & Schaaffhausen's & Bank für & & \\
\hline & $\begin{array}{l}\text { Bergwerksgesel } \\
\text { 1schaft }\end{array}$ & Bergbau AG & $\begin{array}{l}\text { Elektricitätsges } \\
\text { ellschaft }\end{array}$ & $\begin{array}{l}\text { Bergwerksgesel } \\
\text { lschaft }\end{array}$ & cher Bankverein & Handel und & & \\
\hline & Schaaffhausen's & Schaaffhausen's & Schaaffhausen's & $\begin{array}{l}\text { lschatt } \\
\text { Schaaffhausen's }\end{array}$ & \multirow{4}{*}{ Deutsche Bank } & \multirow{4}{*}{ Deutsche Bank } & & \\
\hline & cher Bankverein & cher Bankverein & cher Bankverein & cher Bankverein & & & & \\
\hline & Bank für & Bank für & Bank für & Bank für & & & & \\
\hline & Handel und & Handel und & Handel und & Handel und & & & & \\
\hline & Industrie & Industrie & Industrie & Industrie & Dresdner Bank & Dresdner Bank & & \\
\hline & & & & & Allgemeine & Allgemeine & & \\
\hline & & & & & Elektricitätsges & Elektricitätsges & & \\
\hline & Deutsche Bank & Deutsche Bank & Deutsche Bank & Deutsche Bank & ellschaft & ellschaft & & \\
\hline & & & & & Gelsenkirchener & Gelsenkirchener & & \\
\hline & Dresdner Bank & Dresdner Bank & Dresdner Bank & Dresdner Bank & Bergwerksgesel & Bergwerksgesel & & \\
\hline
\end{tabular}




\section{Appendix 4. Factor betas}

\begin{tabular}{|c|c|c|c|c|c|}
\hline Number & Name & $\begin{array}{l}\text { Market } \\
\text { beta }\end{array}$ & SMB beta & $\begin{array}{l}\text { Momentum } \\
\text { beta }\end{array}$ & $\begin{array}{l}\text { Liquidity risk } \\
\text { beta }\end{array}$ \\
\hline 1 & AG für Anilinfabrikation & 0.9495 & 0.0143 & -0.0134 & -0.0108 \\
\hline & Allgemeine & 1.1106 & 0.1030 & -0.0627 & 0.0010 \\
\hline 2 & Elektricitätsgesellschaft & & & & \\
\hline & Berlin-Anhaltinische & 0.9076 & 0.1870 & -0.1142 & -0.0045 \\
\hline 3 & Maschinenbau & & & & \\
\hline & Bank für Handel und & 0.8529 & -0.1742 & -0.0575 & -0.0018 \\
\hline 5 & Industrie & & & & \\
\hline 6 & Deutsche Bank & 0.7853 & -0.1129 & -0.0406 & -0.0022 \\
\hline 7 & Dresdner Bank & 1.0399 & -0.1269 & 0.0377 & -0.0009 \\
\hline 8 & $\begin{array}{l}\text { Deutsche Jute Spinnerei und } \\
\text { Weberei }\end{array}$ & 0.8506 & 0.7068 & -0.1798 & -0.0169 \\
\hline 9 & Deutsche Spiegelglas & 0.8176 & 0.5646 & -0.6744 & -0.0158 \\
\hline 10 & Erdmannsdorfer Spinnerei & 0.8675 & 0.8082 & 0.0550 & -0.0078 \\
\hline 11 & $\begin{array}{l}\text { Gelsenkirchener } \\
\text { Bergwerksgesellschaft }\end{array}$ & 1.3337 & -0.1197 & -0.0423 & 0.0046 \\
\hline 12 & Gerresheimer Glashütten & 0.4778 & 0.0332 & 0.0519 & -0.0163 \\
\hline 13 & Hallesche Maschinenfabriken & 0.8676 & 0.1832 & 0.1901 & -0.0138 \\
\hline 14 & Harpener Bergbau AG & 1.3313 & -0.1714 & -0.0945 & 0.0006 \\
\hline 15 & $\begin{array}{l}\text { Kattowitzer AG für Bergbau } \\
\text { und Eisen }\end{array}$ & 0.9905 & 0.1479 & 0.2048 & -0.0041 \\
\hline 16 & Maschinenfabrik Kappel & 1.1560 & 1.4812 & -0.3261 & -0.0198 \\
\hline 17 & Norddeutsche Wollkämmerei & 0.8708 & 0.2831 & -0.3059 & 0.0007 \\
\hline 18 & $\begin{array}{l}\text { Oberschlesische Portland- } \\
\text { Cement AG }\end{array}$ & 1.1232 & 0.9108 & 0.0946 & -0.0157 \\
\hline 19 & Rheinische Stahlwerke & 1.4853 & 0.3032 & 0.1581 & -0.0030 \\
\hline 20 & Rositzer Zuckerfabrik & 0.9179 & 0.3928 & 0.5578 & -0.0098 \\
\hline
\end{tabular}




$\begin{array}{llllll}21 & \begin{array}{l}\text { Schaaffhausen'scher } \\ \text { Bankverein }\end{array} & 0.8501 & 0.0479 & -0.1440 & -0.0006 \\ & \begin{array}{l}\text { Chemische Fabrik vormals } \\ 22\end{array} & 0.7953 & 0.0682 & 0.3457 & 0.0109 \\ 23 & \begin{array}{l}\text { Schering } \\ \text { Schlesische Zinkhütten }\end{array} & 0.7238 & 0.2492 & 0.1671 & -0.0201 \\ 24 & \text { Schlesische Leinen-Industrie } & 0.4938 & 0.1729 & -0.2841 & -0.0050 \\ 25 & \text { Schultheiss Brauerei } & 0.4402 & 0.1868 & -0.0431 & -0.0184 \\ 26 & \text { Siemens Glas-Industrie } & 0.6243 & 0.0003 & -0.0755 & -0.0098 \\ 27 & \text { Stettiner Chamottewaren } & 0.9383 & 0.4370 & \mathbf{- 1 . 3 8 7 9} & 0.0001 \\ & \text { Average } & \mathbf{0 . 9 0 7 8} & \mathbf{0 . 2 5 2 9} & \mathbf{- 0 . 0 7 6 3} & \mathbf{- 0 . 0 0 6 9}\end{array}$

Market, SMB and Momentum betas are the slopes of a multiple regression of monthly stock excess returns on all three factor mimicking portfolio returns (Market betas and SMB betas may slightly differ in regressions on two and one factors). Liquidity risk beta is the slope of regression of yearly individual stock illiquidity shocks on excess market returns. 
Appendix 5. Trade volume of stocks in Imperial Germany and proportion of zero return days, 1892-1913

\begin{tabular}{ccc} 
Year & $\begin{array}{c}\text { Trade volume in bill. } \\
\text { mark }\end{array}$ & $\begin{array}{c}\text { Proportion of zero } \\
\text { returns }\end{array}$ \\
\hline 1892 & 72.07 & 0.253 \\
1893 & 45.78 & 0.277 \\
1894 & 73.60 & 0.179 \\
1895 & 79.17 & 0.140 \\
1896 & 51.40 & 0.143 \\
1897 & 63.62 & 0.170 \\
1898 & 59.20 & 0.160 \\
1899 & 71.89 & 0.157 \\
1900 & 59.77 & 0.164 \\
1901 & 47.84 & 0.204 \\
1902 & 50.72 & 0.180 \\
1903 & 53.78 & 0.156 \\
1904 & 56.34 & 0.136 \\
1905 & 80.28 & 0.122 \\
1906 & 63.79 & 0.128 \\
1907 & 38.84 & 0.145 \\
1908 & 37.80 & 0.167 \\
1909 & 73.80 & 0.133 \\
1910 & 84.72 & 0.178 \\
1911 & 87.36 & 0.167 \\
1912 & 91.61 & 0.182 \\
1913 & 60.64 & 0.211 \\
Average & $\mathbf{6 3 . 8 2}$ & $\mathbf{0 . 1 7 1}$ \\
\hline Source: & 1969 &
\end{tabular}

Source: Wetzel (1996), own calculations 


\section{Appendix 8.}

Table A8.1. Results of cross-sectional asset pricing regressions using equally weighted market index returns

\begin{tabular}{|c|c|c|c|c|c|c|}
\hline & (1) & (2) & (3) & (4) & (5) & (6) \\
\hline Constant & $\begin{array}{l}0.0029^{* *} \\
(0.0015)\end{array}$ & $\begin{array}{c}0.0016 \\
(0.0018)\end{array}$ & $\begin{array}{c}0.0008 \\
(0.0020)\end{array}$ & $\begin{array}{c}.0008 \\
(.0020)\end{array}$ & $\begin{array}{l}-.0015 \\
(.0022)\end{array}$ & $\begin{array}{l}-0.0014 \\
(0.0023)\end{array}$ \\
\hline Market beta $\bar{\lambda}_{\beta}$ & $\begin{array}{c}0.0014 \\
(0.0020)\end{array}$ & $\begin{array}{c}0.0005 \\
(0.0022)\end{array}$ & $\begin{array}{c}0.0014 \\
(0.0023)\end{array}$ & $\begin{array}{l}.0021 \\
(.0023)\end{array}$ & $\begin{array}{l}.0029 \\
(.0024)\end{array}$ & $\begin{array}{c}0.0026 \\
(0.0025)\end{array}$ \\
\hline Transaction cost lagged $\bar{\lambda}_{T C}^{\prime}$ & & $\begin{array}{l}0.2423^{* * *} \\
(0.1200)\end{array}$ & $\begin{array}{c}0.0614 \\
(0.1318)\end{array}$ & $\begin{array}{l}.0170 \\
(.1444)\end{array}$ & $\begin{array}{l}.1176 \\
(.1367)\end{array}$ & $\begin{array}{c}0.1271 \\
(0.1511)\end{array}$ \\
\hline SMB beta & & & & & $\begin{array}{l}-.0019 \\
(.0023)\end{array}$ & $\begin{array}{l}-0.0023 \\
(0.0024)\end{array}$ \\
\hline Momentum beta & & & & & & $\begin{array}{r}-0.0006 \\
0.0015\end{array}$ \\
\hline Autocorrelation $\bar{\lambda}_{\rho}$ & & & & $\begin{array}{l}-0.0027 \\
(0.0045)\end{array}$ & & \\
\hline Illiquidity risk premium $\bar{\lambda}_{I}$ & & & $\begin{array}{l}-0.1754^{* *} \\
(0.0693)\end{array}$ & $\begin{array}{c}-.1720^{* * *} \\
(.0718)\end{array}$ & $\begin{array}{c}- \\
.2578^{* * *} \\
(.0839)\end{array}$ & $\begin{array}{c}-0.2622^{* * *} \\
(0.0845)\end{array}$ \\
\hline Average $\mathrm{R}^{2}$ & 0.07 & 0.13 & 0.18 & 0.23 & 0.23 & 0.29 \\
\hline$\#$ of stocks & 26 & 26 & 26 & 26 & 26 & 26 \\
\hline$\#$ of cross-sections $T$ & 264 & 252 & 252 & 252 & 252 & 252 \\
\hline
\end{tabular}

Illiquidity risk premium is cross-sectional coefficient in front of illiquidity beta. Illiquidity beta is regression slope of the regression of errors of VAR(2)-X with two lags of returns for LOT on equally weighted market index excess returns 
Table A8.2. Results of cross-sectional asset pricing regressions using Eube (1998) index for market returns

\begin{tabular}{|c|c|c|c|c|c|c|}
\hline & (1) & (2) & (3) & (4) & (5) & (6) \\
\hline \multirow[t]{2}{*}{ Constant } & $0.0037^{* * *}$ & 0.0014 & 0.0012 & 0.0014 & 0.0014 & 0.0003 \\
\hline & $(.0014)$ & $(.0016)$ & 0.0016 & 0.0016 & 0.0020 & 0.0021 \\
\hline \multirow{2}{*}{ Market beta $\bar{\lambda}_{\beta}$} & 0.0010 & 0.0020 & 0.0023 & 0.0031 & 0.0024 & 0.0030 \\
\hline & $(.0031)$ & $(.0031)$ & 0.0031 & 0.0032 & 0.0032 & 0.0032 \\
\hline \multirow{2}{*}{ Transaction cost lagged $\bar{\lambda}_{T C}^{\prime}$} & & $.2508 * *$ & 0.0866 & 0.0420 & 0.0543 & 0.0971 \\
\hline & & $(.1189)$ & 0.1293 & 0.1427 & 0.1423 & 0.1549 \\
\hline \multirow[t]{2}{*}{ SMB beta } & & & & & 0.0003 & -0.0007 \\
\hline & & & & & 0.0021 & 0.0022 \\
\hline \multirow[t]{2}{*}{ Momentum beta } & & & & & & -0.0010 \\
\hline & & & & & & 0.0015 \\
\hline \multirow{2}{*}{ Autocorrelation $\bar{\lambda}_{\rho}$} & & & & -0.0017 & & \\
\hline & & & & 0.0047 & & \\
\hline \multirow{2}{*}{ Illiquidity risk premium $\bar{\lambda}_{I}$} & & & & $-0.1136^{* *}$ & $-0.1262^{* *}$ & $-0.1456^{* * *}$ \\
\hline & & & $0.1178^{* *}$ & 0.0500 & 0.0504 & 0.0525 \\
\hline Average $\mathrm{R}^{2}$ & 0.06 & 0.12 & $\begin{array}{c}0.0468 \\
0.18\end{array}$ & 0.23 & 0.24 & 0.30 \\
\hline$\#$ of stocks & 26 & 26 & 26 & 26 & 26 & 26 \\
\hline \# of cross-sections $T$ & 264 & 252 & 252 & 252 & 252 & 252 \\
\hline
\end{tabular}

Illiquidity risk premium is cross-sectional coefficient in front of illiquidity beta. Illiquidity beta is regression slope of the regression of errors of VAR(2)-X with two lags of returns for LOT on the Eube (1998) index excess returns 
Appendix 9

Results of cross-sectional asset pricing regressions

\begin{tabular}{|c|c|c|c|c|c|c|}
\hline & & (2) & (3) & (5) & (6) & (7) \\
\hline Constant & $\begin{array}{c}0.0044 * * * \\
0.0014\end{array}$ & $\begin{array}{c}.0006 \\
(.0023)\end{array}$ & $\begin{array}{r}.0003 \\
(.0025)\end{array}$ & $\begin{array}{l}0.0007 \\
0.0024\end{array}$ & $\begin{array}{l}0.0006 \\
0.0025\end{array}$ & $\begin{array}{l}0.0010 \\
0.0024\end{array}$ \\
\hline Market beta $\bar{\lambda}_{\beta}$ & $\begin{array}{c}-0.0002 \\
0.0020\end{array}$ & $\begin{array}{c}.0021 \\
(.0022)\end{array}$ & $\begin{array}{c}.0030 \\
(.0023)\end{array}$ & $\begin{array}{l}0.0033 \\
0.0024\end{array}$ & $\begin{array}{l}0.0024 \\
0.0023\end{array}$ & $\begin{array}{l}0.0023 \\
0.0023\end{array}$ \\
\hline$\%$ of zero returns p. a. & & $\begin{array}{l}.0113 * \\
(.0064)\end{array}$ & $\begin{array}{c}.0077 \\
(.0064)\end{array}$ & $\begin{array}{l}0.0012 \\
0.0065\end{array}$ & $\begin{array}{l}0.0050 \\
0.0062\end{array}$ & $\begin{array}{l}0.0034 \\
0.0062\end{array}$ \\
\hline SMB & & & & & $\begin{array}{l}0.0006 \\
0.0018\end{array}$ & $\begin{array}{l}0.0005 \\
0.0018\end{array}$ \\
\hline Momentum & & & & & & $\begin{array}{l}0.0005 \\
0.0015\end{array}$ \\
\hline Autocorrelation & & & & $\begin{array}{r}-0.0066 \\
0.0043\end{array}$ & & \\
\hline Illiquidity risk premium $\bar{\lambda}_{I}$ & & & $\begin{array}{l}-.0052 * * \\
(.0026)\end{array}$ & $\begin{array}{c}-0.0050 * \\
0.0026\end{array}$ & $\begin{array}{c}-0.0042 * \\
(.0025)\end{array}$ & $\begin{array}{c}-0.0045^{*} \\
(.0024)\end{array}$ \\
\hline Average $\mathrm{R}^{2}$ & 0.07 & 0.11 & 0.16 & 0.20 & 0.22 & 0.28 \\
\hline \# of stocks & 26 & 26 & 26 & 26 & 26 & 26 \\
\hline$\#$ of cross-sections $T$ & 264 & 252 & 252 & 252 & 252 & 252 \\
\hline
\end{tabular}

Estimates of the Fama-MacBeth (1973) regressions for the sample period from 1892 to 1913 for 26 companies. Reported coefficient values $\bar{\lambda}_{k}$ are averages of 264 (252 for columns (2)-(7)) regression estimates of the type: $Z_{i t}=\alpha_{t}+\lambda_{t}^{\prime} B_{i t}+u_{i}$, where $\lambda_{t}^{\prime}$ denotes the transposed vector of risk premia and $B_{i t}$ denotes the vector of risk factor loadings, which serve as explanatory variables in each cross section. Standard errors are calculated as $\sqrt{\operatorname{var}\left[\lambda_{k t}\right] \cdot\left(1+\mu^{\prime} \Omega^{-1} \mu\right) / T}$, according to the Fama-MacBeth (1973) procedure with the Shanken (1992) correction, and are reported in parentheses. Values marked with ***,** and * are significant at the $1 \%, 5 \%$ and $10 \%$ level respectively. Average $R^{2}$ is an arithmetic mean of $R^{2}$ for each crosssection. 
Appendix 10.

Table A10.1 Conditional risk-premia model for the proportion of zero returns

\begin{tabular}{|c|c|c|c|c|}
\hline \multirow[t]{2}{*}{ Parameter } & \multicolumn{2}{|c|}{ VAR(2)-DVEC } & \multicolumn{2}{|c|}{ VAR(2)-DCC } \\
\hline & Return & Illiquidity & Return & Illiquidity \\
\hline \multirow[t]{2}{*}{ intercept } & 0.0132 & $0.0463 * * *$ & 0.0067 & $0.0447 * * *$ \\
\hline & $(0.0089)$ & $(0.0078)$ & $(0.0082)$ & $(0.0079)$ \\
\hline \multirow[t]{2}{*}{ Return $_{t-1}$} & 0.0852 & $-0.3740 * * *$ & 0.0877 & $-0.3536 * * *$ \\
\hline & $(0.0682)$ & $(0.0932)$ & $(0.0595)$ & $(0.0892)$ \\
\hline \multirow{2}{*}{ Return $_{t-2}$} & $-0.2000 * * *$ & 0.0058 & $-0.2003 * * *$ & 0.0063 \\
\hline & $(0.0715)$ & $(0.0840)$ & $(0.0650)$ & $(0.0834)$ \\
\hline \multirow[t]{2}{*}{ Illiquidity $_{t-1}$} & -0.0284 & $0.6114 * * *$ & -0.0255 & $0.6277 * * *$ \\
\hline & $(0.0409)$ & $(0.0622)$ & $(0.0399)$ & $(0.0615)$ \\
\hline \multirow{2}{*}{ Illiquidity $_{t-2}$} & -0.0388 & $0.1099 *$ & -0.0272 & 0.1015 \\
\hline & $(0.0433)$ & $(0.0630)$ & $(0.0395)$ & $(0.0622)$ \\
\hline \multirow[t]{2}{*}{ VarRet $_{t}$} & 0.4643 & & 6.6010 & \\
\hline & $(16.0204)$ & & (18.2559) & \\
\hline \multirow[t]{2}{*}{ CovRetIl $_{t}$} & $-41.1100 * * *$ & & $-25.3989 * * *$ & \\
\hline & $(15.0851)$ & & $(8.1023)$ & \\
\hline \multirow[t]{2}{*}{ const } & $5.04 \times 10^{-5}$ & $3.50 \times 10^{-5}$ & $2.35 \times 10^{-5}$ & $3.19 \times 10^{-5}$ \\
\hline & $\left(4.48 \times 10^{-5}\right)$ & $\left(2.36 \times 10^{-5}\right)$ & $\left(2.15 \times 10^{-5}\right)$ & $\left(2.15 \times 10^{-5}\right)$ \\
\hline \multirow[t]{2}{*}{ Arch } & 0.0753 & 0.0299 & $0.0430 *$ & 0.0362 \\
\hline & $(0.0495)$ & $(0.0281)$ & $(0.0254)$ & $(0.0277)$ \\
\hline \multirow[t]{2}{*}{ GARCH } & $0.7988 * * *$ & $0.9191 * * *$ & $0.9009 * * *$ & $0.9214 * * *$ \\
\hline & $(0.1417)$ & $(0.0496)$ & $(0.0616)$ & $(0.0514)$ \\
\hline Const cov & \multicolumn{2}{|c|}{$\begin{array}{c}8.0 \times 10^{-7} \\
\left(3.57 \times 10^{-6}\right)\end{array}$} & & \\
\hline ARCH cov / & \multicolumn{2}{|c|}{$0.0335^{*}$} & \multicolumn{2}{|c|}{$0.0563 *$} \\
\hline DCC alpha & \multicolumn{2}{|c|}{$(0.0176)$} & \multicolumn{2}{|c|}{$(0.0298)$} \\
\hline GARCH cov / & \multicolumn{2}{|c|}{$0.9080 * * *$} & \multicolumn{2}{|c|}{$0.9437 * * *$} \\
\hline DCC beta & \multicolumn{2}{|c|}{$(0.0369)$} & \multicolumn{2}{|c|}{$(0.0315)$} \\
\hline LB 10 & 6.50 & 14.01 & 6.13 & 14.60 \\
\hline (p-value) & $(0.77)$ & $(0.17)$ & $(0.80)$ & $(0.15)$ \\
\hline McLeod-Li 10 & 8.70 & 6.47 & 8.64 & 6.18 \\
\hline (p-value) & $(0.56)$ & $(0.77)$ & $(0.56)$ & $(0.80)$ \\
\hline Multivariate & \multirow{2}{*}{\multicolumn{2}{|c|}{$\begin{array}{l}32.63 \\
(079)\end{array}$}} & \multicolumn{2}{|c|}{32.84} \\
\hline Q 10 (p-value) & & & \multicolumn{2}{|c|}{$(0.78)$} \\
\hline Log & & & \multirow{2}{*}{\multicolumn{2}{|c|}{1212.6115}} \\
\hline Likelihood & \multicolumn{2}{|c|}{1218.8932} & & \\
\hline Obs & & 62 & & 52 \\
\hline
\end{tabular}

Estimates of the equation parameters of VAR(2)-MGARCH-in-mean models (DVEC, DCC) for market monthly excess returns and aggregate market illiquidity described in Eq. 11-12 for the sample period from 1892 to 1913 . Aggregate market illiquidity is calculated as average of the zero return day proportions of all stocks included into the index. Values marked with $* * *, * *$ and $*$ are significant at the $1 \%, 5 \%$ and $10 \%$ level respectively. 
Regression of realized liquidity risk premiums (resulting from the conditional risk-premia model with proportion of zero return days as illiquidity measure and parameters provided in Table A10.1, DCC specification)

$$
\begin{aligned}
& L R P_{t}=\underset{(0.0095)}{0.0252}-\underset{(0.3232)}{0.0138} \cdot \Delta \% G D P p^{0 . c_{t-1}}-\underset{(0.3214)}{0.8439} \cdot \Delta \% G D P p . c_{t-2}+\underset{(0.0138)}{0.1299 \cdot B C_{t-1}}+\varepsilon_{t} \\
& R^{2}=84.4 \% \quad L B_{1}=0.79 \quad L B_{3}=3.76
\end{aligned}
$$

Regression of realized liquidity risk premiums (resulting from the conditional risk-premia model with proportion of zero return days as illiquidity measure and parameters provided in Table A10.1, DVEC specification)

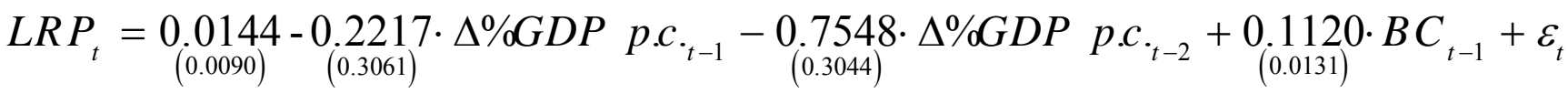

$$
\begin{aligned}
& R^{2}=81.8 \% \quad L B_{1}=1.02 \quad L B_{3}=1.99
\end{aligned}
$$

